\title{
New targeted treatments for non-small-cell lung cancer - role of nivolumab
}

\author{
Giulia Zago, ${ }^{1, *}$ \\ Mirte Muller',* \\ Michel van den Heuvel' \\ Paul Baas' \\ 'Department of Thoracic Oncology, \\ The Netherlands Cancer Institute, \\ Antoni van Leeuwenhoek (NKI-AvL), \\ Amsterdam, the Netherlands; ${ }^{2}$ Medical \\ Oncology 2, Istituto Oncologico \\ Veneto (IOV), Padova, Italy \\ *These authors contributed equally to \\ this work
}

\author{
This article was published in the following Dove Press journal: \\ Biologics:Targets and Therapy \\ I August 2016 \\ Number of times this article has been viewed
}

\begin{abstract}
Non-small-cell lung cancer (NSCLC) is often diagnosed at an advanced stage of disease, where it is no longer amenable to curative treatment. During the last decades, the survival has only improved significantly for lung cancer patients who have tumors harboring a driver mutation. Therefore, there is a clear unmet need for effective therapies for patients with no mutation. Immunotherapy has emerged as an effective treatment for different cancer types. Nivolumab, a monoclonal inhibitory antibody against PD-1 receptor, can prolong survival of NSCLC patients, with a manageable toxicity profile. In two Phase III trials, nivolumab was compared to docetaxel in patients with, respectively, squamous (CheckMate 017) and nonsquamous NSCLC (CheckMate 057). In both trials, nivolumab significantly reduced the risk of death compared to docetaxel ( $41 \%$ and $27 \%$ lower risk of death for squamous and non-squamous NSCLC, respectively). Therefore, nivolumab has been approved in the US and in Europe as second-line treatment for advanced NSCLC. Unfortunately, accurate predictive factors for patient selection are lacking, making it difficult to decide who will benefit and who will not. Currently, there are many ongoing trials that evaluate the efficacy of nivolumab in different settings and in combination with other agents. This paper reviews the present literature about the role of nivolumab in the treatment of NSCLC. Particular attention has been given to efficacy studies, toxicity profile, and current and emerging predictive factors.
\end{abstract}

Keywords: nivolumab, advanced non-small-cell lung cancer, immunotherapy, anti-PD-1

\section{Introduction}

Lung cancer is the leading cause of cancer death worldwide, with 1.825 million diagnoses and 1.59 million deaths in $2012,{ }^{1}$ and is the most commonly diagnosed malignancy in males. The major cause of lung cancer is smoking, which is responsible for $80 \%$ of cases in males and $50 \%$ of cases in females. ${ }^{2}$ Non-small-cell lung cancer (NSCLC) accounts for $\sim 85 \%-90 \%$ of all lung cancers. The two major subtypes are non-squamous cell (mainly adenocarcinoma) and squamous cell carcinomas. ${ }^{3,4}$ In the majority of cases, patients are diagnosed at an advanced, unresectable stage of disease. For these patients, the treatment has a palliative intent, aiming to control symptoms and prolong survival.

In the last decades, the discovery of genomic heterogeneity of NSCLCs has radically changed the diagnostic approach for these patients. With the advent of new techniques (integrating morphological analysis, immunohistochemistry, and molecular testing), different subclasses of NSCLCs have been defined (Figure 1). ${ }^{5}$ Targetable alterations are the key elements for personalized treatments and are nowadays part of
Correspondence: Paul Baas

Department of Thoracic Oncology,

The Netherlands Cancer Institute,

Antoni van Leeuwenhoek (NKI-AvL),

Plesmanlaan 121, 1066 CX Amsterdam,

the Netherlands

Tel +3I 205122958

Fax +3I 205122572

Email p.baas@nki.nl 


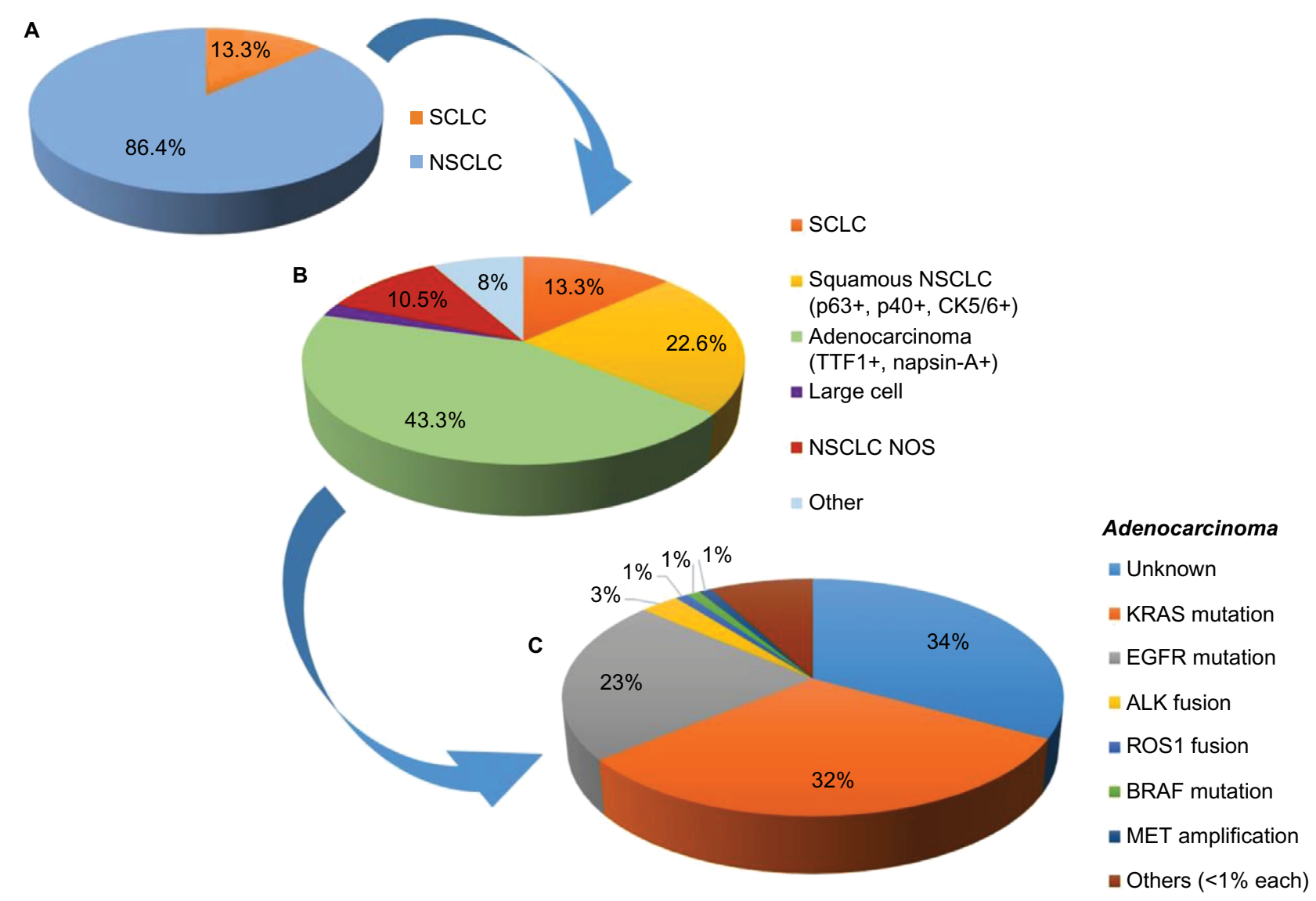

Figure I Multistep process for the diagnosis and characterization of lung cancer.

Notes: (A) The two main lung cancer subtypes, SCLC and NSCLC, can be discriminated by a morphological analysis. NSCLC accounts for $\sim 85 \%-90 \%$ of all lung cancers. (B) Immunohistochemistry allows different NSCLC subtypes to be distinguished. (C) Molecular testing allows possible driver mutations in the tumor to be identified (EGFR and ALK). Analysis of ROSI, BRAF, and MET should be considered for selected patients. Data from National Cancer Institute ${ }^{73}$ and Naidoo et al. ${ }^{5}$

Abbreviations: SCLC, small-cell lung cancer; NSCLC, non-small-cell lung cancer; NOS, non-squamous.

the standard of care for NSCLC patients. However, a targetable driver mutation is detectable only in $10 \%-20 \%$ of all NSCLCs in the Caucasian population (Table 1). ${ }^{4-6}$ For the others, chemotherapy has been the only available option so far, with dismal results.

In the last years, new agents have been developed which enhance the host immune response against the tumor. Immune checkpoint inhibitors have been shown to be highly active in different malignancies. ${ }^{7}$ The anti-PD-1 monoclonal antibody (mAb) nivolumab has recently been shown to induce a significant survival benefit in NSCLC patients, with either squamous or non-squamous histology, compared to standard second-line chemotherapy, ${ }^{8,9}$ thus providing a new treatment option in this setting.

The aim of this paper is to present the standard of treatment and review the clinical data about the role of nivolumab in the treatment of NSCLC, in terms of efficacy, safety, and patients' quality of life (QoL).

\section{Current and emerging treatment options for NSCLC}

Until recently, chemotherapy has been the only available option for patients diagnosed with NSCLC not amenable to radical-intent local treatment. First-line chemotherapy doublet regimens, based on platinum compounds (cisplatin or carboplatin) combined with a third-generation agent (vinorelbine, gemcitabine, paclitaxel, docetaxel, pemetrexed), prolong survival and improve QoL. ${ }^{10-12}$ Mono-chemotherapy is considered the treatment of choice both as second line and for unfit or elderly patients. ${ }^{3}$ In the last decade, with the discovery of driver mutations in a variable percentage of NSCLCs (mainly in never smokers or light former smokers, with a non-squamous histology), targeted therapies have emerged as new standard of care in this setting (Table 1). For tumors with an activating mutation, in the HER domain, EGFR-tyrosine kinase inhibitors, gefitinib, erlotinib, and afatinib, have shown higher efficacy, in terms of response 
Table I Driver mutations, and current and emerging targeted treatments in NSCLC

\begin{tabular}{|c|c|c|c|}
\hline $\begin{array}{l}\text { Molecular } \\
\text { alteration }\end{array}$ & Frequency & $\begin{array}{l}\text { Targeted } \\
\text { agent }\end{array}$ & Studies and findings \\
\hline \multirow[t]{5}{*}{$\begin{array}{l}\text { EGFR } \\
\text { mutation } \\
\text { (exon } 19-21)\end{array}$} & $\begin{array}{l}\text { Caucasian } \\
\text { pts: } 10 \%-15 \% \\
\text { NSCLCs }\end{array}$ & Gefitinib & $\begin{array}{l}\left.\text { IPASS (Mok et al }\left.\right|^{13}\right) \text { : first-line gefitinib is superior to carbo-paclitaxel in terms of RR } \\
(71 \% \text { vs } 47 \% \text { ) and PFS ( } 9.5 \text { vs } 6.3 \text { months) in Asian, nonsmoker pts, with ADC } \\
\left.\text { NEJSG002 (Maemondo et } \mathrm{al}^{74}\right) \text { : first-line gefitinib is superior to carbo-paclitaxel in terms of RR } \\
(73 \% \text { vs } 30 \%) \text { and PFS ( } 10.8 \text { vs } 5.4 \text { months) in EGFR+ ADC }\end{array}$ \\
\hline & $\begin{array}{l}\text { Asian pts: } 50 \% \\
\text { NSCLCs }\end{array}$ & Erlotinib & $\begin{array}{l}\text { EURTAC (Rosell et } \text { al }^{\mid 4} \text { ): first-line erlotinib is superior to platinum-based ChT for RR } \\
(58 \% \text { vs } 15 \% \text { ) and PFS ( } 9.7 \text { vs } 5.2 \text { months) in Caucasian pts with EGFR+ ADC }\end{array}$ \\
\hline & $\begin{array}{l}\text { Common } \\
\text { mutation: exon }\end{array}$ & Afatinib & $\begin{array}{l}\left.\text { LUX-Lung } 3 \text { (Sequist et al }{ }^{15}\right) \text { : first-line afatinib is superior to Cis-Pem for RR ( } 56 \% \text { vs } 23 \% \text { ) and } \\
\text { PFS (II vs } 6.9 \text { months) in EGFR+ ADC }\end{array}$ \\
\hline & $\begin{array}{l}19 \text { deletion: } \\
45 \% \text {; exon } 21\end{array}$ & & $\begin{array}{l}\left.\left.\text { LUX-Lung } 6 \text { (Wu et al }{ }^{16}\right) \text { : first-line afatinib is superior to Cis-Pem for RR ( } 67 \% \text { vs } 23 \%\right) \text { and PFS } \\
\text { (II vs } 5.6 \text { months) in EGFR+ ADC }\end{array}$ \\
\hline & L858R: $40 \%$ & & $\begin{array}{l}\text { Pooled analysis LUX-Lung } 3 / 6\left(\text { Yang et } \mathrm{a}^{75}\right) \text { : first-line afatinib improves OS ( } 31.7 \text { vs } \\
20.7 \text { months) for EGFR exon } 19 \text { deletion ADC compared to platinum-based ChT }\end{array}$ \\
\hline $\begin{array}{l}\text { EGFR } \\
\text { mutation } \\
\text { (exon } 20\end{array}$ & $\begin{array}{l}\text { Acquired } \\
\text { resistance to } \\
\text { first-line EGFR }\end{array}$ & AZD929I & $\begin{array}{l}\left.\text { AZD929I Phase I (Jänne et al }{ }^{19}\right) \text { : AZD929I is effective in pts with T790M+ and T790M-ADC, } \\
\text { after a previous TKI treatment, with DCR =84\% (T790M+: } 95 \% ; \text { T790M-: 61\%) and median PFS } \\
=8.2 \text { months (T790M+: } 9.6 \text { months; T790M-: } 2.8 \text { months) }\end{array}$ \\
\hline T790M) & TKI: $50 \%$ pts & $\begin{array}{l}\text { CO-1686 } \\
\text { (rociletinib) }\end{array}$ & $\begin{array}{l}\left.\text { CO- } 1686 \text { Phase I/II (Sequist et } \mathrm{a}^{20}\right) \text { : rociletinib achieves high DCR in pretreated, Caucasian, } \\
\text { T790M+ }(93 \%) \text { and T790M- }(59 \%) \text { ADC pts, with median PFS I3.I months for T790M+ pts } \\
\text { (82\% pts censored) }\end{array}$ \\
\hline \multirow[t]{3}{*}{$\begin{array}{l}\text { ALK } \\
\text { translocation }\end{array}$} & $2 \%-7 \%$ NSCLCs & Crizotinib & $\begin{array}{l}\left.\text { PROFILE I007 (Shaw et al }{ }^{17}\right) \text { : crizotinib is superior to Pem or docetaxel as second-line therapy } \\
\text { in ALK+ NSCLC, in terms of RR ( } 65 \% \text { vs } 20 \%) \text { and PFS ( } 7.7 \text { vs } 3 \text { months) } \\
\left.\text { PROFILE I0I4 (Solomon et a }{ }^{16}\right) \text { : crizotinib is superior to platinum-Pem as first-line therapy in } \\
\text { ALK+ NSCLC, in terms of RR }(74 \% \text { vs } 45 \%) \text { and PFS ( } 10.9 \text { vs } 7 \text { months) }\end{array}$ \\
\hline & & Ceritinib & $\begin{array}{l}\text { ASCEND-I Phase I (Shaw et } \mathrm{a}^{21} \text { ): ceritinib is effective for ALK+ NSCLCs, both pretreated with } \\
\text { or naïve to crizotinib ( } R R=58 \% \text {; PFS }=7 \text { months) }\end{array}$ \\
\hline & & Alectinib & $\begin{array}{l}\left.\text { AF-00IJP Phase I/II (Seto et } \mathrm{al}^{22}\right) \text { : alectinib is effective for the treatment of ALK+ crizotinib-naïve } \\
\text { pts (RR }=93.5 \%) \\
\left.\text { AF-002JG Phase I/II (Gadgeel et a }{ }^{23}\right) \text { : alectinib is effective for the treatment of } \\
\text { ALK+ crizotinib-resistant pts (RR }=55 \% \text {; PFS =N/R) }\end{array}$ \\
\hline $\begin{array}{l}\text { ROSI } \\
\text { rearrangement }\end{array}$ & $1 \%-2 \%$ NSCLCs & Crizotinib & $\begin{array}{l}\text { Phase I (Shaw et al }{ }^{24} \text { ): crizotinib achieves } 72 \% \text { ORR in pts with ROSI-rearranged NSCLC; } \\
\text { estimated median duration of response: } 17.6 \text { months; median PFS: } 19.2 \text { months }\end{array}$ \\
\hline $\begin{array}{l}\text { MET } \\
\text { amplification }\end{array}$ & $<1 \%$ ADC & Crizotinib & $\begin{array}{l}\left.\text { Ongoing Phase I trial NCT00585 I } 95 \text { (PROFILE I00I) (Camidge et a }{ }^{25}\right) \text { : } \\
\text { I } 3 \text { pts (low/intermediate/high level of amplification) } \\
4 \text { PR (mainly highly amplified NSCLCs); } 6 \text { ongoing at data-cutoff } \\
\text { Diarrhea }(50 \%) \text {, nausea and vomiting }(3 \mathrm{I} \%) \text {, peripheral edema }(25 \%)\end{array}$ \\
\hline \multirow[t]{2}{*}{$\begin{array}{l}\text { BRAF V } 600 E \\
\text { mutation }\end{array}$} & $<2 \%$ NSCLCs & Dabrafenib & 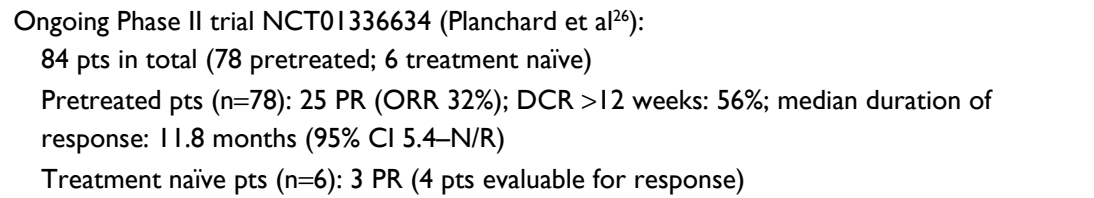 \\
\hline & & $\begin{array}{l}\text { Dabrafenib } \\
+ \text { trametinib } \\
\text { (MEK-inhibitor) }\end{array}$ & $\begin{array}{l}\text { Ongoing Phase II trial NCTOI } 336634 \text { (Planchard et } \mathrm{a}^{27} \text { ): } \\
33 \text { pts ( } 24 \text { pts evaluable for response) } \\
\text { Response ( } n=24) \text { : I5 PR (ORR 63\%); DCR }>12 \text { weeks: } 88 \% \\
\text { Common AEs ( }>20 \% \text { ): pyrexia, diarrhea, nausea, vomiting, peripheral edema, rash. Grade 3-4 } \\
\text { AEs: } 39 \% \text { pts }\end{array}$ \\
\hline $\begin{array}{l}\text { HER2 } \\
\text { mutation }\end{array}$ & $\begin{array}{l}3 \% \text { ADC }(2 \% \\
\text { NSCLCs })\end{array}$ & $\begin{array}{l}\text { Trastuzumab or } \\
\text { afatinib }\end{array}$ & $\begin{array}{l}\text { Retrospective (Mazieres et al } \mathrm{a}^{77} \text { ): } \\
65 \text { pts HER2 exon } 20 \text { mutation; } 16 \text { pts received HER2-targeted therapy } \\
\text { ORR }=50 \% \text {; overall DCR }=82 \% \text { (trastuzumab: } 96 \% \text {; afatinib: } 100 \% \text { ) } \\
\text { PFS for HER2-targeted therapies: } 5.1 \text { months }\end{array}$ \\
\hline $\begin{array}{l}\text { RET } \\
\text { rearrangement }\end{array}$ & $1 \%-2 \%$ ADC & Cabozantinib & $\begin{array}{l}\text { Ongoing Phase II trial NCTOI639508 (Drilon et } \mathrm{al}^{78} \text { ): } \\
5 \text { pts: } 3 \text { evaluable for response to treatment with cabozantinib } \\
\text { Early and durable response }\end{array}$ \\
\hline
\end{tabular}

Note: EGFR+ represents EGFR mutation positive (ie, activating mutations).

Abbreviations: NSCLC, non-small-cell lung cancer; pts, patients; RR, response rate; PFS, progression-free survival; ADC, adenocarcinoma; ChT, chemotherapy; Cis, cisplatin; Pem, pemetrexed; OS, overall survival; TKI, tyrosine kinase inhibitor; DCR, disease control rate; N/R, not reported; ORR, overall response rate; PR, partial response; $\mathrm{Cl}$, confidence interval; $\mathrm{AEs}$, adverse events. 
rate (RR) and progression-free survival (PFS), compared to chemotherapy. ${ }^{13-16}$ Similar results have been achieved by the ALK-tyrosine kinase inhibitors crizotinib and ceritinib, in tumors with ALK rearrangement. ${ }^{17,18,21}$ More recently, new primary or acquired targetable molecular alterations have been identified, such as ROS1 rearrangement, MET amplification, and HER2 mutation. A number of Phase I and II trials have shown encouraging results (Table 1), ${ }^{19-28}$ so molecular testing is now recommended for these genes in selected patients.

Recently, new immune-modulating drugs have been developed which target different immune checkpoints, with the aim of enhancing the host immune response against tumor cells. For patients with NSCLC, the best results have been shown by PD-1/PD-L1 immune checkpoint inhibitors, which might have a higher activity in high-mutational load tumors. ${ }^{29}$ Nivolumab (Opdivo $^{\circledR}$; Bristol-Myers Squibb, New York, NY, USA; other names: BMS-936558, MDX-1106, ONO-4538), a PD-1-blocking antibody, has been approved by the US Food and Drug Administration (FDA) as second-line treatment for squamous NSCLC in March 2015. In October 2015, the FDA expanded its approved use to all NSCLCs (both squamous and non-squamous histology) that have progressed after a first-line platinum-based chemotherapy. ${ }^{8,9}$

\section{Pharmacology of nivolumab Mechanism of action and pharmacodynamics}

Nivolumab is a fully human IgG4 immune checkpoint inhibitory antibody, which binds to PD-1, preventing its interaction with its ligands PD-L1 (also called B7-H1 or CD274) and PD-L2 (also called B7-DC or CD273) (Figure 2). ${ }^{30,31} \mathrm{PD}-1$ is an immune-regulatory receptor expressed by activated T-cells, and it is induced during any inflammatory reaction. PD-1 is also highly expressed by $\mathrm{CD}^{+}$regulatory $\mathrm{T}$ (Treg) cells, and its main role is to limit immune response and maintain immune tolerance within peripheral tissues, ${ }^{32,33}$ by both limiting the activity of effector T-cells and enhancing activity of inhibitory Treg cells. ${ }^{30}$ Therefore, the

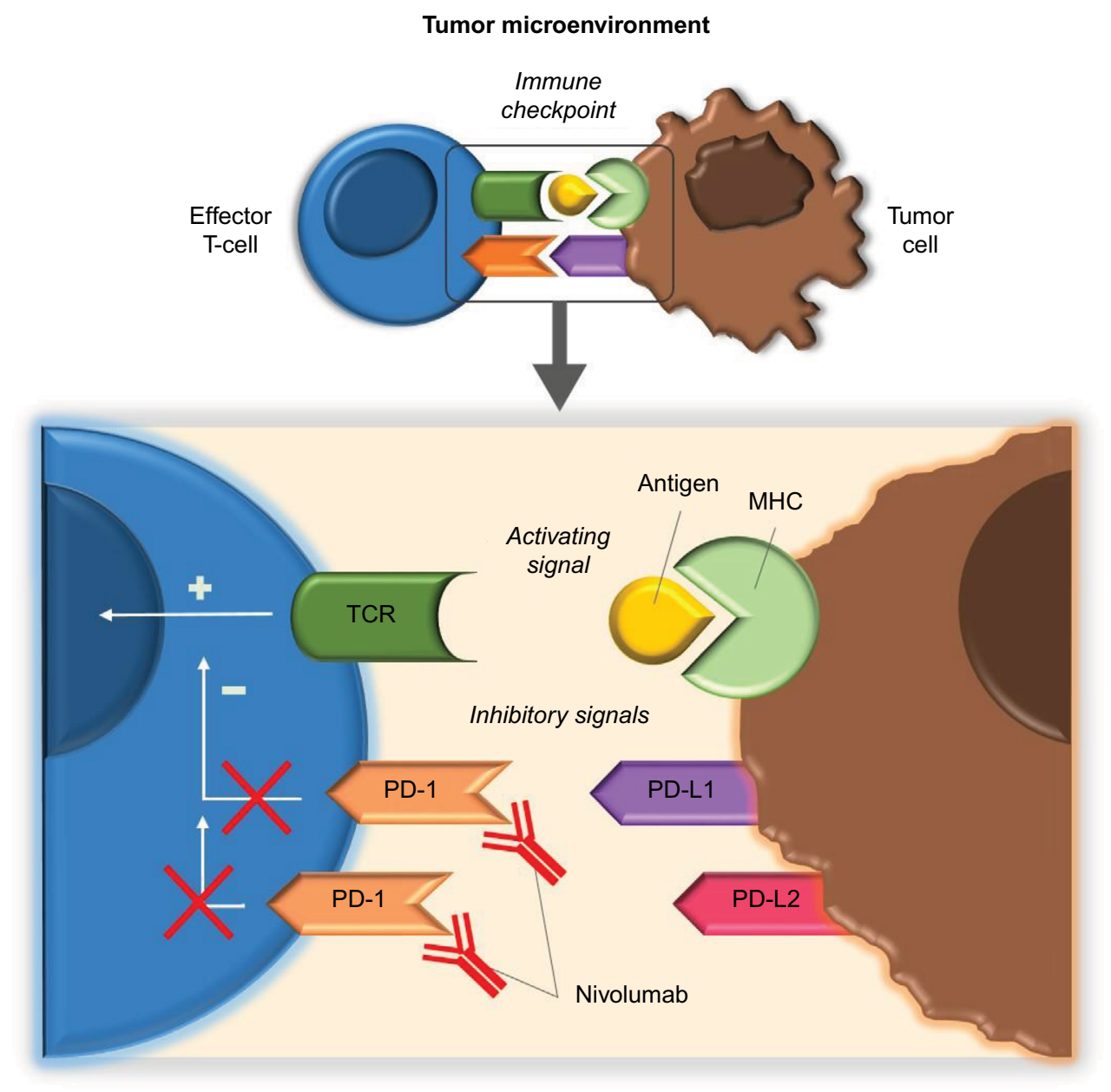

Figure 2 Immuno-modulatory role of PD-I receptor and mechanism of action of nivolumab.

Abbreviations: MHC, major histocompatibility complex; TCR, T-Cell Receptor; PD-I, programmed death I; PD-LI, programmed death I - ligand I; PD-L2, programmed death I - ligand 2. 
interaction of nivolumab with PD-1 attenuates the negative signals of PD-1/PD-L1, thus enhancing the host antitumor immune response. Tumor infiltrating lymphocytes have been found to express PD-1 in different cancer types, while the upregulation of PD-L1 by tumor cells has been interpreted as a possible mechanism of resistance of the tumor to the host immune response. ${ }^{30,34}$ Lastly, PD-1-deficient mice showed a mild, late-onset immunological phenotype compared to the CTLA4-deficient ones, suggesting a more tolerable toxicity profile. These observations, taken all together, provided the basis for starting the development of new PD-1-targeted immunomodulatory compounds. ${ }^{7}$

Preclinical studies have demonstrated that antibodymediated PD-1/PD-L1 pathway blockade leads to an increase in T-cell count (both effector and antigen-specific) and modulates cytokines secretion in vitro and in murine models. ${ }^{35,36}$ The inhibition of PD-1 interaction with its ligand PD-L1, by specific mAbs, was able to rescue cytolytic immune antitumor activity, leading to tumor regression in mice. ${ }^{34}$

The interaction of nivolumab with PD-1 receptor was evaluated using purified human T-cells from peripheral blood. ${ }^{37}$ Nivolumab binds with high affinity to PD-1 on effector and memory T-cells and on Treg cells, ${ }^{37}$ thus preventing its interaction with PD-L1 and PD-L2. Neither $\mathrm{CD}^{+}{ }^{+}$- nor $\mathrm{CD} 8^{+}$-naïve T-cells are bound by nivolumab, ${ }^{37}$ reflecting the pattern of expression of PD-1, which is upregulated in activated T-cells in peripheral tissues. ${ }^{30}$ Preclinical data showed that nivolumab binds to PD-1 on activated human $\mathrm{CD}^{+}{ }^{+}$T-cells with a halfmaximal effective concentration $\left(\mathrm{EC}_{50}\right)$ of $0.64 \mathrm{nmol} / \mathrm{L}$ and inhibits PD-1 interaction with its ligands (PD-L1 and PD-L2) with a half-maximal inhibitory concentration $\left(\mathrm{IC}_{50}\right)$ of 2.52 and $2.59 \mathrm{nmol} / \mathrm{L}$, respectively. ${ }^{37}$ The high affinity of nivolumab for PD-1 has been confirmed in the first-in-human Phase I study by the analysis of PD-1 occupancy on circulating T-cells, which was demonstrated to be dose independent. Mean peak occupancy was $85 \%$ (range: $70 \%-97 \%$ ), and the mean plateau occupancy was $72 \%$ (range: $59 \%-81 \%$ ), detected after 4 hours to $>57$ days after the first infusion. ${ }^{38}$ Plateau occupancy was maintained even when serum levels were undetectable. ${ }^{38}$ Repeated infusions of nivolumab $10 \mathrm{mg} / \mathrm{kg}$ led to troughs and peaks of PD-1 occupancy around each dose, but $100 \%$ occupancy was not achieved. ${ }^{38}$

\section{Pharmacokinetics}

Nivolumab is administered by intravenous infusion within 30-60 minutes. Pharmacokinetic data from the first-in-human Phase I trial demonstrated a half-life ranging between 12 (for subjects receiving the lowest doses: $0.3,1$, or $3 \mathrm{mg} / \mathrm{kg}$ ) and
20 days (for subjects receiving the highest dose of $10 \mathrm{mg} / \mathrm{kg}$ ), with a maximum serum concentration directly related to administered dose within 4 hours after administration. ${ }^{38,39}$ No maximum dose has been defined..$^{38,39}$

\section{Nivolumab and NSCLC Efficacy studies}

Preclinical studies showed that nivolumab/PD-1 interaction leads to enhanced T-cell reactivity in vitro, in the presence of an antigen or another T-cell receptor stimulus. ${ }^{37}$ Moreover, $\mathrm{mAb}$ inhibition of PD-1/PD-L1 interaction was able to rescue a cytolytic immune antitumor activity and lead to tumor regression in mice. ${ }^{34}$

A Phase I trial with expansion cohorts was conducted between 2008 and 2012 (Figure 3 and Table 2), aiming to assess activity and safety of biweekly nivolumab at a dose of $1-10 \mathrm{mg} / \mathrm{kg}$. A total of 296 heavily pretreated patients with advanced tumor were enrolled, including melanoma, NSCLC, renal cell carcinoma, and prostate and colorectal cancer. About one in four to one in five patients experienced durable objective response (OR), in particular those with melanoma, NSCLC, and renal cell cancer. ${ }^{39}$ Given the encouraging results observed for NSCLCs, both in terms of RR and duration of response (DOR), an efficacy analysis based on data from a prolonged follow-up was carried out for this group of patients. In total, 129 patients with NSCLC underwent a median follow-up of 39 months (range: 32-66 months) and were evaluated for overall survival (OS), RR, and DOR.$^{40}$ Overall, median OS was 9.9 months (95\% confidence interval [CI] 7.8-12.4), with a 1-, 2-, and 3-year survival rate of $42 \%, 24 \%$, and $18 \%$, respectively, without significant differences between squamous and non-squamous histologies. OS was longer for patients receiving nivolumab at the dose of $3 \mathrm{mg} / \mathrm{kg}$ (median OS $=14.9$ months, 95\% CI 7.3-30.3), which was the dose of choice for the subsequent Phase III trials. Across all doses, overall response rate (ORR) was $17 \%$, for both histological subtypes, but was higher for patients receiving 3 or $10 \mathrm{mg} /$ $\mathrm{kg}$ doses compared to $1 \mathrm{mg} / \mathrm{kg}$. Median estimated DOR for responders was 17 months, and an additional $10 \%$ of patients experienced long-lasting stability of disease (ie, stable disease $[\mathrm{SD}] \geq 24$ weeks) ${ }^{40}$

Given these encouraging results, a Phase II trial (CheckMate 063) was conducted between 2012 and 2013 (Figure 3 and Table 2) to investigate the efficacy of biweekly nivolumab $3 \mathrm{mg} / \mathrm{kg}$, in patients with advanced squamous NSCLCs that had progressed after at least one platinum-based chemotherapy regimen and one more subsequent line of treatment. The efficacy of nivolumab was confirmed in this highly 


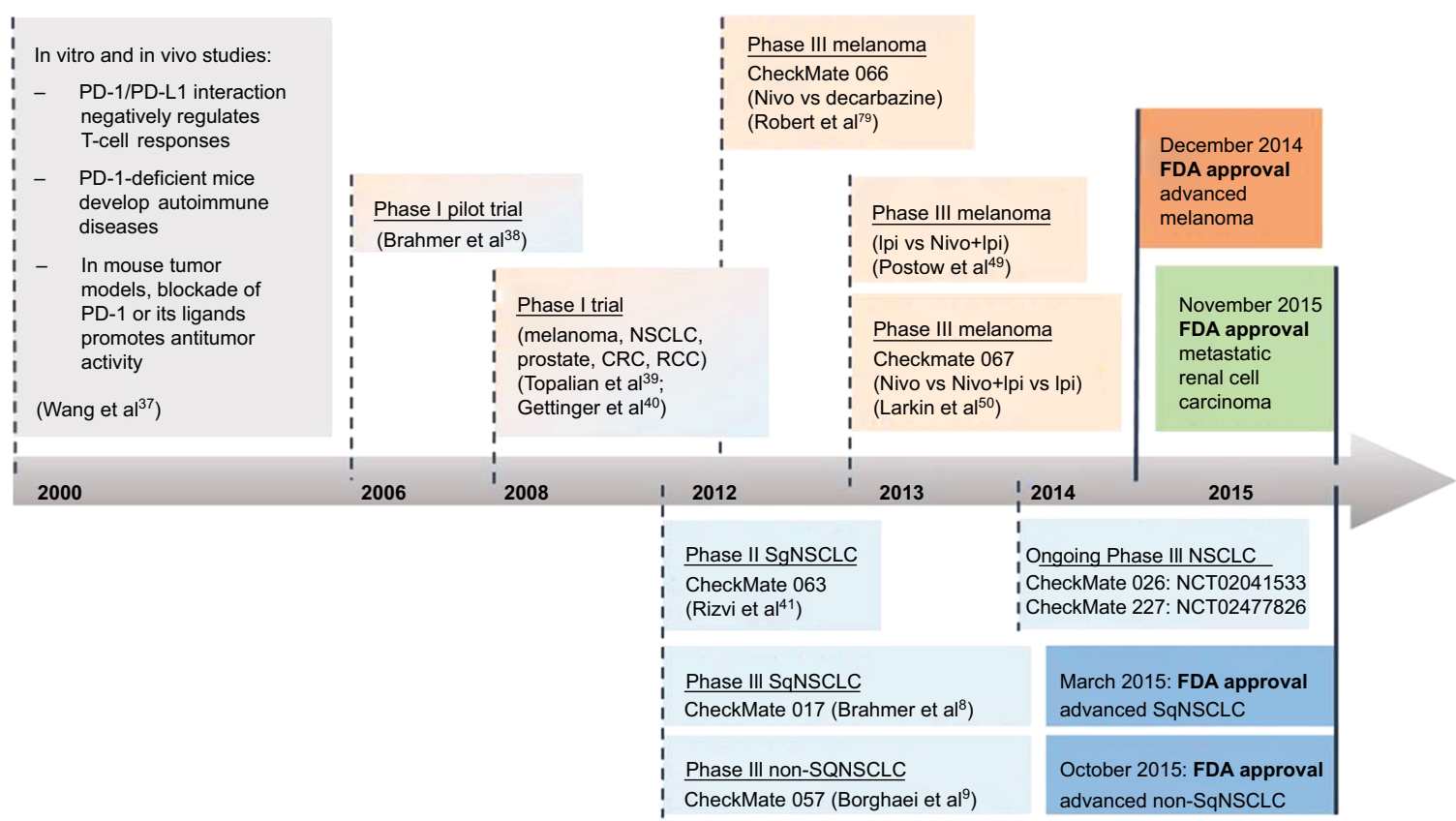

Figure 3 Nivolumab development, from preclinical experience to clinical approval: focus on NSCLC.

Notes: Timeline of nivolumab development from the preclinical studies to US FDA approval (dotted lines represent the starting date of the related trial).

Abbreviations: PD-I, programmed death I; PD-LI, programmed death I - ligand I; NSCLC, non-small-cell lung cancer; CRC, colorectal cancer; RCC, renal cell carcinoma; Nivo, nivolumab; Ipi, ipilimumab; FDA, US Food and Drug Administration; SqNSCLC, squamous NSCLC.

refractory group of patients, with $14.5 \%$ subjects achieving a partial response (PR) and $26 \% \mathrm{SD}$, with a high proportion of patients experiencing a durable response, in both groups. ${ }^{41}$ Updated survival data were presented during the 2015 World Conference on Lung Cancer (WCLC). ${ }^{42}$ Out of 17 patients who achieved a PR, 13 (76\%) had ongoing responses; thus, median DOR was not reached. Overall, median OS was 8.2 months (95\% CI 6.1-10.9), and 1-year OS rate was $41 \%$. Two Phase II Japanese trials achieved similar results in terms of ORR. Nivolumab-treated squamous NSCLC $(\mathrm{n}=35)$ showed an ORR of $25.7 \%$ (95\% CI 14.2-42.1), while the ORR of non-squamous NSCLC ( $\mathrm{n}=76)$ was $19.7 \%(95 \%$ CI 12.3-30.0). ${ }^{43}$

The results achieved in the Phase II trial were confirmed by the two subsequent Phase III trials of second-line treatment nivolumab (Figure 3). CheckMate 017 and CheckMate 057 aimed to compare second-line treatment nivolumab (given biweekly at the dose of $3 \mathrm{mg} / \mathrm{kg}$ ) to standard-ofcare docetaxel monotherapy ( $75 \mathrm{mg} / \mathrm{m}^{2}$, every 3 weeks), in advanced squamous (272 patients) and non-squamous (582 patients) NSCLC patients, respectively. ${ }^{89}$ In both trials, nivolumab significantly reduced the risk of death compared to docetaxel ( $41 \%$ and $27 \%$ lower risk of death for squamous and non-squamous histologies, respectively). For patients with squamous NSCLC, median OS was 9.2 months $(95 \%$ CI 7.3-13.3) in the nivolumab group and 6 months (95\% CI 5.1-7.3) in the control group, while for non-squamous
NSCLC, OS was 12.2 months (95\% CI 9.7-15.0) with nivolumab and 9.4 months (95\% CI 8.1-10.7) with docetaxel. At 18 months of analysis, the OS rate was $28 \%$ vs $13 \%$ for squamous and $39 \%$ vs $23 \%$ for non-squamous carcinoma. Moreover, subgroup analysis from CheckMate 057 identified a lack of survival benefit with nivolumab in never smokers and EGFR-mutated tumors, albeit a small patient population. ${ }^{9}$ This is in line with the Phase I trial, where nivolumab achieved a higher RR among current and former smokers compared to never smokers. ${ }^{40}$ Both observations may find an explanation in the higher mutational load of smoking-induced tumors, which can lead to the production of a higher number of tumor-associated neo-antigens. ${ }^{44}$

The results of previous trials have been recently confirmed in a large ( $\mathrm{n}=824)$ ongoing study (CheckMate 153) conducted in community-based oncology centers. Among patients with advanced pretreated NSCLC, until now, no differences have been reported in terms of safety. ${ }^{45}$ Among the 395 patients evaluable for tumor response, 55 (14\%) experienced a PR, and 194 (49\%), a SD. No differences have been observed according to PD-L1 status or baseline performance status. ${ }^{45}$

A number of trials are currently ongoing (Table 2 and Figure 3 ) evaluating the role of nivolumab (alone or in combination) as first-line treatment for advanced NSCLC. Preliminary results from the Phase I trial CheckMate 012 (ClinicalTrials.gov: NCT01454102) have been presented during the 2015 American Society of Clinical Oncology 
Table 2 Main trials evaluating nivolumab in NSCLC patients, from Phase I to Phase III trials, and preliminary results of ongoing trials.

\begin{tabular}{|c|c|c|c|c|}
\hline Trial & Phase and line & Treatment & Patients & Findings \\
\hline $\begin{array}{l}\text { (Gettinger et } \mathrm{al}^{40} . \\
\text { J Clin Oncol, 20I5) }\end{array}$ & $\begin{array}{l}\text { Phase I } \\
\text { Pretreated }\end{array}$ & $\begin{array}{l}\text { Nivolumab, q2w: } \\
\text { - I mg/kg }\end{array}$ & 129 pts & $\begin{array}{l}\text { ORR: } 17 \% \text {. ORR by dose: } 3 \% \text { (Nivo I mg/kg), } 24 \% \text { (Nivo } 3 \mathrm{mg} / \mathrm{kg} \text { ), and } 20 \% \\
\text { (Nivo } 10 \mathrm{mg} / \mathrm{kg} \text { ) }\end{array}$ \\
\hline NCT00730639 & NSCLC & $\begin{array}{l}-3 \mathrm{mg} / \mathrm{kg} \\
-10 \mathrm{mg} / \mathrm{kg}\end{array}$ & & $\begin{array}{l}\text { Higher ORR in heavy smokers (>5 pack/years) } \\
\text { Estimated duration of response: } 17 \mathrm{~m} \text {. Long lasting SD ( } 24 \text { weeks): } 10 \% \\
\text { Median OS: } 9.9 \mathrm{~m} \mathrm{(} 95 \% \mathrm{Cl}, 7.8 \text { to } 12.4 \text { ); Nivo } 3 \mathrm{mg} / \mathrm{kg} \text { OS: } 14.9 \mathrm{~m} \text {; } \\
\text { Nivo I mg/kg OS } 9.2 \mathrm{~m} ; 10 \mathrm{mg} / \mathrm{kg} 8.6 \mathrm{~m}\end{array}$ \\
\hline $\begin{array}{l}\text { CheckMate } 063 \\
{\text { (Rizvi et al }{ }^{41} .}^{\text {Lancet Oncol, } 2015)} \\
\text { NCTOI72I } 759\end{array}$ & $\begin{array}{l}\text { Phase II } \\
\text { third line } \\
\text { SqNSCLC }\end{array}$ & $\begin{array}{l}\text { Nivolumab } \\
-3 \mathrm{mg} / \mathrm{kg}, \mathrm{q} 2 \mathrm{w}\end{array}$ & I 17 pts & $\begin{array}{l}\text { Response: } \mathrm{PR}=14.5 \%(95 \% \mathrm{Cl} 8.7 \text { to } 22.2) \text { SD }=26 \%(95 \% \mathrm{Cl}, 18 \text { to } 35) \\
\text { Median duration of response: not reached }(95 \% \mathrm{Cl}, 8.3 \mathrm{~m}-\mathrm{N} / \mathrm{R}) \text {; median } \\
\text { duration of SD: } 6 \mathrm{~m}(95 \% \mathrm{Cl}, 4.7 \text { to } 10.9) \\
\text { Median OS: } 8.2 \mathrm{~m}(95 \% \mathrm{Cl}, 6.1 \text { to } 10.9)\end{array}$ \\
\hline $\begin{array}{l}\text { CheckMate } 017 \\
\left(\text { Brahmer et } \mathrm{al}^{8} .\right. \\
\text { N Engl J Med, } 2015) \\
\text { NCTOI642004 }\end{array}$ & $\begin{array}{l}\text { Phase III } \\
\text { second line } \\
\text { SqNSCLC }\end{array}$ & $\begin{array}{l}\text { Nivolumab } \\
\text { vs } \\
\text { docetaxel }\end{array}$ & $\begin{array}{l}135 \text { pts } \\
\text { vs } \\
137 \text { pts }\end{array}$ & $\begin{array}{l}\text { ORR: nivolumab } 20 \%(95 \% \mathrm{Cl}, \mathrm{I} 4 \text { to } 28) \text { vs Docetaxel } 9 \%(95 \% \mathrm{Cl}, 5 \text { to I5) } \\
(P=0.008) \\
\text { Median OS: nivolumab } 9.2 \mathrm{~m}(95 \% \mathrm{Cl}, 7.3 \text { to } 13.3) \text { vs Docetaxel } 6 \mathrm{~m}(95 \% \mathrm{Cl} \text {, } \\
5 . \mathrm{I} \text { to } 7.3) \\
\text { Risk of death } 4 \mathrm{I} \% \text { lower with nivolumab }(\mathrm{HR}=0.59 ; 95 \% \mathrm{Cl}, 0.44 \text { to } 0.79 \text {; } \\
P<0.00 \mathrm{I})\end{array}$ \\
\hline $\begin{array}{l}\text { CheckMate } 057 \\
\text { (Borghaei et al'., } \\
\text { N Engl J Med, } 2015 \text { ) } \\
\text { NCTOI } 673867\end{array}$ & $\begin{array}{l}\text { Phase III } \\
\text { second line } \\
\text { Non-SqNSCLC }\end{array}$ & $\begin{array}{l}\text { Nivolumab } \\
\text { vs } \\
\text { docetaxel }\end{array}$ & $\begin{array}{l}287 \text { pts } \\
\text { vs } \\
268 \text { pts }\end{array}$ & $\begin{array}{l}\text { ORR: nivolumab I9\% }(95 \% \mathrm{Cl} \text {, I5 to } 24) \text { vs Docetaxel I2\% }(95 \% \mathrm{Cl}, 9 \text { to } 17) \\
(P=0.02) \\
\text { Median OS: Nivo } 12.2 \mathrm{~m}(95 \% \mathrm{Cl}, 9.7 \text { to I5) vs Docetaxel } 9.4 \mathrm{~m}(95 \% \mathrm{Cl}, 8 . \mathrm{I} \\
\text { to } 10.7) \\
\text { Risk of death } 27 \% \text { lower with nivolumab }(\mathrm{HR}=0.73 ; 95 \% \mathrm{Cl}, 0.59 \text { to } 0.89 \\
P=0.002)\end{array}$ \\
\hline $\begin{array}{l}\text { CheckMate } 012 \\
\text { (Gettinger et } \mathrm{al}^{46} \text {, } \\
\text { J Clin Oncol, } 2015 \\
\text { [suppl; abstr } 8025] \text { ) }\end{array}$ & $\begin{array}{l}\text { Phase I } \\
\text { first line } \\
\text { NSCLC }\end{array}$ & $\begin{array}{l}\text { Nivolumab } \\
-3 \mathrm{mg} / \mathrm{kg}, \mathrm{q} 2 \mathrm{w}\end{array}$ & & $\begin{array}{l}\text { Ongoing. Clin Trial Gov: NCT0I454I02 (CheckMate 0I2) } \\
\text { [Safety study of nivolumab in combination with Cis/Gem, Cis/Pem, } \\
\text { Carbo/Paclitaxel, Bevacizumab maintenance, Erlotinib, ipilimumab or as } \\
\text { monotherapy in pts with stage IIIB/IV NSCLC] } \\
\text { Nivolumab cohort: ORR =2I\%. Median duration of response: not reached } \\
\text { (range, } 7.6+, 85.6+\text { weeks) } \\
\text { Median OS: } 98.3 \text { weeks (range, I.0 to I04.4+) }\end{array}$ \\
\hline $\begin{array}{l}\text { CheckMate } 012 \\
\left(\text { Rizvi et } \text { al }^{48} ., 16^{\text {th }}\right. \\
\text { World Conference on } \\
\text { Lung Cancer, 2015) }\end{array}$ & $\begin{array}{l}\text { Phase I } \\
\text { first line } \\
\text { NSCLC }\end{array}$ & $\begin{array}{l}\text { Nivolumab + } \\
\text { ipilimumab } \\
\text { (multiple doses) }\end{array}$ & $\begin{array}{l}\text { I48 pts } \\
\text { (4 cohorts) }\end{array}$ & $\begin{array}{l}\text { Ongoing. Clin Trial Gov: NCT0I454I02 (CheckMate 0I2) } \\
\text { [Safety study of nivolumab in combination with Cis/Gem, Cis/Pem, } \\
\text { Carbo/Paclitaxel, Bevacizumab maintenance, Erlotinib, ipilimumab or as } \\
\text { monotherapy in pts with stage IIIB/IV NSCLC] } \\
\text { Nivo+lpi cohort: ORR: I3\% to } 39 \% \text {; median PFS: } 4.9 \text { to } 10.6 \text { m }\end{array}$ \\
\hline $\begin{array}{l}\text { Carbone et } \mathrm{al}^{47} \text {, J Clin } \\
\text { Oncol, 20I4 (suppl; } \\
\text { abstr TPS8I82) }\end{array}$ & $\begin{array}{l}\text { Phase III } \\
\text { first line } \\
\text { PD-LI+NSCLC }\end{array}$ & $\begin{array}{l}\text { Nivolumab + } \\
\text { vs } \\
\text { ICC }\end{array}$ & $\begin{array}{l}\text { Estimated } \\
\text { total: } \\
535 \text { pts }\end{array}$ & $\begin{array}{l}\text { Ongoing. Clin Trial Gov: NCT0204I533 (CheckMate 026) } \\
\text { Primary objective: PFS With nivolumab vs ICC in pts with strong PD-LI } \\
\text { expression }\end{array}$ \\
\hline $\begin{array}{l}\text { CheckMate } 227 \\
\text { ClinTrial.gov: } \\
\text { NCT02477826 }\end{array}$ & $\begin{array}{l}\text { Phase III } \\
\text { first line or } \\
\text { recurrent } \\
\text { NSCLC }\end{array}$ & $\begin{array}{l}\text { Nivolumab vs } \\
\text { Nivo+ipi vs } \\
\text { Nivo+ChT vs } \\
\text { ChT }\end{array}$ & $\begin{array}{l}\text { Estimated } \\
\text { total: } \\
1980 \text { pts }\end{array}$ & $\begin{array}{l}\text { Ongoing. Clin Trial Gov: NCT02477826 (CheckMate } 227 \text { ) } \\
\text { An open-label, trial of nivolumab, or nivolumab plus ipilimumab, or nivolumab } \\
\text { plus platinum-doublet chemotherapy vs platinum doublet chemotherapy in } \\
\text { subjects with stage IV NSCLC }\end{array}$ \\
\hline
\end{tabular}

Notes: Docetaxel dose in Phase III trials was $75 \mathrm{mg} / \mathrm{m}^{2}$; if not otherwise specified, nivolumab dose should be intended as $3 \mathrm{mg} / \mathrm{kg}$, q2w.

Abbreviations: NSCLC, non-small-cell lung cancer; CRC, colorectal cancer; RCC, renal cell carcinoma; Ipi, ipilimumab; SqNSCLC, squamous NSCLC; ORR, overall response rate; $\mathrm{SD}$, stable disease; $\mathrm{Cl}$, confidence interval; OS, overall survival; PR, partial response; N/R, not reported; HR, hazard ratio; PFS, progression-free survival; ICC, investigator's choice chemotherapy; ChT, chemotherapy; q2w, biweekly; Cis, cisplatin; Gem, gemcitabine; Pem, pemetrexed; Carbo, carboplatin; m, months; pts, patients.

(ASCO) Annual Meeting. In the cohort of the 52 chemotherapy-naïve patients who received nivolumab monotherapy, an ORR of $21 \%$, with long DOR (median DOR not reached; range: $7.6+, 85.6+$ weeks), was reported. ${ }^{46} \mathrm{~A}$ Phase III trial (CheckMate 026, ClinicalTrials.gov: NCT02041533), comparing the first-line nivolumab to investigator's choice chemotherapy, in PD-L1-positive NSCLC, is currently ongoing. ${ }^{47}$

During the 2015 WCLC, a manageable toxicity profile of nivolumab in combination with the CTLA4 immune checkpoint inhibitor ipilimumab (Yervoy ${ }^{\mathrm{TM}}$; Bristol-Myers Squibb; other names: MDX-010, MDX-101), in patients with NSCLC was reported. The ORR was 13\%-39\% across the four cohorts treated with different nivolumab and ipilimumab doses, but higher partial RRs were seen among patients who received nivolumab $3 \mathrm{mg} / \mathrm{kg}$, and the median PFS was 4.9-10.6 months. ${ }^{48}$ Thus, given also the positive results achieved by the same combination in advanced melanoma patients, ${ }^{49,50}$ a Phase III trial is currently ongoing (CheckMate 227, ClinicalTrials.gov: NCT02477826) aiming to evaluate 
the OS of NSCLC patients receiving first-line nivolumab monotherapy, or nivolumab in combination with ipilimumab or chemotherapy, versus chemotherapy alone.

Other anti-PD1 and anti-PD-L1 compounds are currently under investigation as single agents or in combination for the treatment of NSCLC. Among the anti-PD-1 compounds, pembrolizumab (Keytruda ${ }^{\circledR}$; Merck Sharp \& Dohme Corp., Kenilworth, NJ, USA) was demonstrated to prolong OS compared to docetaxel, either at the dose of 2 (HR 0.71 , $95 \%$ CI $0.58-0.88, P=0.0008$ ) or $10 \mathrm{mg} / \mathrm{kg}$ (HR $0.61,95 \%$ CI $0.49-0.75, P<0.0001) .{ }^{51}$ It has been approved by the FDA for the treatment of advanced NSCLC in October 2015. Results from Phase I and II trials are currently available about the role of the anti-PD-L1 compounds atezolizumab (or MPDL3280A) and durvalumab (or MEDI4736) in the treatment of NSCLC. In particular, results from the randomized Phase II trial POPLAR showed longer OS for atezolizumab compared to docetaxel (HR 0.73, 95\% CI 0.53-0.99, $P=0.04$ ), in NSCLC patients after failure of a first-line platinum-based therapy. Moreover, the OS improvement correlated with PD-L1 expression. ${ }^{52}$ No trials are currently available comparing efficacy and safety of these compounds.

\section{Radiological evaluation and immune-related unconventional pattern of response}

In the previous Phase I-III trials, the efficacy of nivolumab has been evaluated using the Response Evaluation Criteria in Solid Tumors v1.1 (RECIST v1.1) guidelines, ${ }^{53}$ which are currently considered the gold standard. Nevertheless, the kinetics of response of new immunomodulatory compounds may differ from that of chemotherapy. Due to their mechanism of action, checkpoint inhibitors such as nivolumab can lead to tumor infiltration by activated T-cells, which can sometimes radiologically appear as an increased tumor burden soon after the start of treatment. ${ }^{54}$ This "pseudo-progression" can eventually be followed by tumor response, in a time frame ranging from 6 weeks to 6 months. Since radiological features are not currently available to definitively discriminate pseudo-progression from real tumor spread, treatment continuation beyond radiological progression can be considered for clinically stable patients. ${ }^{54}$ Moreover, taking into account these particular features, new guidelines for response evaluation of immune therapy have been proposed. ${ }^{54}$

An unconventional pattern of response, described as RECIST v1.1-defined progressive disease followed by PR or SD as defined per protocol, was described in a relatively low percentage of NSCLC patients treated with nivolumab. Across the Phase II and III trials, $-3 \%-7 \%$ of patients experienced an unconventional response. In particular, out of 117 highly pretreated patients who received nivolumab in the Phase II trial, ${ }^{41,42} 22$ patients were treated beyond progression, and four (3.4\% of the total) met criteria for unconventional benefit. This proportion was slightly higher in the two Phase III trials: an unconventional response was seen in nine $(6.8 \%)$ out of 131 nivolumab-treated squamous NSCLCs (28 patients treated beyond progression) ${ }^{8}$ and in 16 (5.5\%) out of 292 nivolumab-treated non-squamous NSCLCs (71 patients treated beyond progression). ${ }^{9}$

\section{Predictive value of PD-LI expression and emerging predictors of response to anti- PD-I therapy}

In advanced NSCLCs, nivolumab monotherapy achieves RRs of $\sim 20 \%{ }^{8,9}$ Therefore, predictive factors are desirable both to select patients who can more likely benefit from anti-PD-1 treatment and for economic reasons.

Various trials, evaluating different PD-1/PD-L1 pathway inhibitors in different tumor types, have described conflicting results about the role of PD-L1 expression on tumor cells in predicting the response to treatment. Therefore, a large metaanalysis (20 trials; 1,475 patients) was conducted in order to explore the role of PD-L1 as predictive factor. ${ }^{55}$ Among the overall population (including patients with melanoma, NSCLC, and genitourinary cancer), treated with either a PD-1 or a PD-L1 inhibitor, a significantly higher RR was described for PDL1-positive patients, compared to the PD-L1-negative patients (ORR: $34.1 \%$ vs $19.9 \%, P<0.0001$ ). The difference was also significant in the subgroup of patients treated with nivolumab (absolute difference: $16.4 \%, 95 \%$ CI 10.0-22.7, $P<0.0001$ ) and among patients with NSCLC (absolute difference: $8.7 \%$, 95\% CI 1.1-15.5, $P=0.02) .{ }^{55}$ However, this study also pointed out that a non-negligible proportion of PD-L1-negative patients still respond to anti-PD-1 or anti-PD-L1 treatments.

For nivolumab-treated NSCLC patients, available data are still controversial so far (Table 3). Results from a nonrandomized subset of 61 pretreatment specimens from 42 patients enrolled in the Phase I trial suggested a role for PD-L1 expression in predicting response to nivolumab, with $36 \%$ OR among PD-L1-positive patients and no OR among PD-L1-negative patients. ${ }^{39}$ Out of the ten patients with NSCLC evaluable for PD-L1 expression in this preliminary analysis, five were PD-L1 positive, and one of them (with $10 \%$ positive tumor cells) achieved a PR with nivolumab $10 \mathrm{mg} /$ $\mathrm{kg}$. However, in a bigger cohort of NSCLCs, no association was seen between PD-L1 status and either ORR or OS. ${ }^{40}$ Data from Phase III trials favored nivolumab in squamous 
Table 3 Correlation between PD-LI expression and clinical response to nivolumab in NSCLC

\begin{tabular}{|c|c|c|c|}
\hline Study & $\begin{array}{l}\text { Evaluable specimens } \\
\text { (pts, } n)\end{array}$ & $\begin{array}{l}\text { PD-LI cut-off } \\
\text { (\% pos tumor cells) }\end{array}$ & Findings \\
\hline \multirow{4}{*}{$\begin{array}{l}\text { Topalian et al, }{ }^{39} \text { Phase } \\
\text { I (melanoma, NSCLC, } \\
\text { prostate cancer, CRC, } \\
\text { RCC) }\end{array}$} & 61 specimens, 42 pts & $\geq 5 \%$ & 25 pos $/ 42$ pts $\rightarrow$ OR: 9 pts (36\%) \\
\hline & (I8 melanoma, I0 & & 17 neg/42 pts $\rightarrow$ OR: none \\
\hline & NSCLC, 7 CRC, 5 RCC, & & Data suggestive for a relationship between PD-LI expression and OR \\
\hline & 2 prostate cancer) & & \\
\hline \multirow{2}{*}{$\begin{array}{l}\text { Gettinger et al, }{ }^{40} \text { Phase I } \\
\text { (prolonged FU NSCLC) }\end{array}$} & 68 pts & $\geq 5 \%$ & 33 pos/68 pts $\rightarrow$ ORR: I5\%; median OS: 7.8 months $(95 \% \mathrm{Cl}, 5.6$ to \\
\hline & & & 21.7 months) \\
\hline \multirow[t]{3}{*}{ NCT00730639 } & & & 35 neg/68 pts $\rightarrow$ ORR: I4\%; median OS: 10.5 months $(95 \%$ Cl, 5.2 \\
\hline & & & to 14.8 months) \\
\hline & & & No association between PD-LI status and ORR or OS \\
\hline \multirow{2}{*}{$\begin{array}{l}\text { Rizvi et al, }{ }^{41} \text { Phase II } \\
\text { (squamous NSCLC), }\end{array}$} & 76 pts & $\geq 1 \%$ & PD-LI pos $(\geq 1 \%) \rightarrow$ ORR: $20 \%$ \\
\hline & & & PD-LI neg $(<1 \%) \rightarrow$ ORR: I3\% \\
\hline CheckMate 063 & & $\geq 5 \%$ & PD-LI pos $(\geq 5 \%) \rightarrow$ ORR: $24 \%$ \\
\hline \multirow[t]{5}{*}{ NCT01721759 } & & & PD-LI neg $(<5 \%) \rightarrow$ ORR: I $4 \%$ \\
\hline & & $\geq 10 \%$ & PD-LI pos $(\geq 10 \%) \rightarrow$ ORR: $24 \%$ \\
\hline & & & PD-LI neg $(<10 \%) \rightarrow$ ORR: I4\% \\
\hline & & & OR numerically higher in PD-LI-pos NSCLCs; no differences among \\
\hline & & & different levels of PD-LI expression \\
\hline \multirow{3}{*}{$\begin{array}{l}\text { Brahmer et al, }{ }^{8} \text { Phase } \\
\text { III (squamous NSCLC), } \\
\text { CheckMate } 017\end{array}$} & 225 pts ( 117 received & $\geq 1 \%$ & PD-LI pos $(\geq 1 \%) \rightarrow$ ORR: $17 \%$ \\
\hline & nivolumab) & & PD-LI neg $(<1 \%) \rightarrow$ ORR: I7\% \\
\hline & & $\geq 5 \%$ & PD-LI pos $(\geq 5 \%) \rightarrow$ ORR: $21 \%$ \\
\hline \multirow[t]{5}{*}{ NCT0I642004 } & & & PD-LI neg $(<5 \%) \rightarrow$ ORR: I5\% \\
\hline & & $\geq 10 \%$ & PD-LI pos $(\geq 10 \%) \rightarrow$ ORR: $19 \%$ \\
\hline & & & PD-LI neg $(<10 \%) \rightarrow$ ORR: $16 \%$ \\
\hline & & & PD-LI expression has no predictive or prognostic value; nivolumab is \\
\hline & & & more effective than docetaxel despite PD-LI level \\
\hline \multirow{8}{*}{$\begin{array}{l}\text { Borghaei et al, }{ }^{9} \\
\text { Phase III (non-squamous } \\
\text { NSCLC), CheckMate } \\
057\end{array}$} & 455 pts $(231$ received & $\geq 1 \%$ & PD-LI pos $(\geq 1 \%) \rightarrow$ ORR: $31 \%$ \\
\hline & nivolumab) & & PD-LI neg $(<1 \%) \rightarrow$ ORR: $9 \%$ \\
\hline & & $\geq 5 \%$ & PD-LI pos $(\geq 5 \%) \rightarrow$ ORR: $36 \%$ \\
\hline & & & PD-LI neg $(<5 \%) \rightarrow$ ORR: $10 \%$ \\
\hline & & $\geq 10 \%$ & PD-LI pos $(\geq 10 \%) \rightarrow$ ORR: $37 \%$ \\
\hline & & & PD-LI neg $(<10 \%) \rightarrow$ ORR: II\% \\
\hline & & & Strong predictive association between PD-LI expression and outcome \\
\hline & & & (ORR, PFS, OS) at all expression levels \\
\hline \multirow{4}{*}{$\begin{array}{l}\text { Rizvi et al, }{ }^{48} \text { Phase I } \\
\text { (NSCLC), } \\
\text { CheckMate } 012\end{array}$} & II3 pts (nivolumab + & $\geq 1 \%$ & PD-LI pos $(\geq 1 \%) \rightarrow$ ORR: $8 \%-48 \%$ (across different dose regimens ${ }^{\mathrm{a}}$ ) \\
\hline & ipilimumab) & & PD-LI neg $(<\mid \%) \rightarrow$ ORR: $0 \%-22 \%$ (across different dose regimens $\left.{ }^{a}\right)$ \\
\hline & & & Clinical activity was observed regardless of tumor PD-LI expression; \\
\hline & & & preliminary evidence of greater activity in $\geq 1 \% \mathrm{PD}$-LI-pos tumors \\
\hline
\end{tabular}

Note: ${ }^{2}$ Dose regimens included: nivolumab I mg/kg + ipilimumab I mg/kg, q3w; nivolumab I mg/kg, q2w + ipilimumab I mg/kg, q6w; nivolumab 3 mg/kg, q2w + ipilimumab I mg/kg, q $12 \mathrm{w}$; nivolumab $3 \mathrm{mg} / \mathrm{kg}$, q2w + ipilimumab I mg/kg, q6w.

Abbreviations: NSCLC, non-small-cell lung cancer; pts, patients; pos, positive; CRC, colorectal cancer; RCC, renal cell carcinoma; OR, objective response; neg, negative; FU, follow-up; ORR, overall response rate; PD-LI, programmed death I - ligand I; PFS, progression-free survival; OS, overall survival.

NSCLC despite PD-L1 expression, ${ }^{8}$ while for non-squamous NSCLCs, PD-L1 expression seemed to be predictive of better nivolumab efficacy in terms of ORR, PFS, and OS. ${ }^{9}$ Across different trials, ORs and longer DORs have been registered both in PD-L1-positive and PD-L1-negative NSCLCs, even if numerically higher among positive tumors, ${ }^{41,46}$ and no differences have been described for different levels of PD-L1 expression ( $1 \%, 5 \%$, or $10 \%$ positive tumor cells). ${ }^{8,9,41,42}$

The predictive role of PD-L1 expression has also been investigated in trials evaluating other anti-PD-1 compounds, such as pembrolizumab. ${ }^{51,56}$ In the Phase II/III study Keynote-010, PD-L1-positive (ie, PD-L1 expression $\geq 1 \%$ of tumor cells) NSCLC patients treated with pembrolizumab achieved a longer median OS compared to those receiving docetaxel (pembrolizumab $2 \mathrm{mg} / \mathrm{kg}$ : 10.4 months; pembrolizumab $10 \mathrm{mg} / \mathrm{kg}$ : 12.7 months; docetaxel $75 \mathrm{mg} / \mathrm{m}^{2}$ : 8.5 months). This survival advantage was higher for patients with $\geq 50 \%$ of PD-L1-positive tumor cells, despite the dose of pembrolizumab they received (HR 0.54 for pembrolizumab $2 \mathrm{mg} / \mathrm{kg}$ vs docetaxel, 95\% CI $0.38-0.77, P=0.0002) .{ }^{51}$

Most nivolumab trials evaluated PD-L1 expression retrospectively on archival tumor samples, using an automated immunohistochemical assay (Dako Denmark A/S, Glostrup, Denmark). Different assays are currently available for the 
evaluation of PD-L1 expression, but an FDA blueprint project is ongoing to solve the differences between the registered kits. ${ }^{57,58}$ Unfortunately, the population tested is heterogeneous, and the PD-L1 expression in tumors seems to be heterogeneous. ${ }^{57}$ This makes the interpretation of current data uncertain. However, the absence of univocal results suggests that PD-L1 expression might not be the only predictor of response to immune checkpoint inhibitors. ${ }^{58}$

Recent data support the hypothesis that tumor's mutation burden could influence the response to PD-1 inhibitors. In fact, the efficacy of PD-1 inhibitors such as nivolumab is based on the ability of T-cells to recognize tumor-related antigens that are presented on the tumor cell surface by major histocompatibility complexes (Figure 2). In particular, neo-antigens (ie, neo-epitopes deriving from tumor-specific DNA mutations) seem to play an important role in tumor immune control, ${ }^{44}$ as suggested by the sporadic observation of systemic tumor response after local radiotherapy. ${ }^{59}$ The likelihood of formation of neo-antigens that can be recognized by host T-cells is expected to be higher in tumors with a high mutational load, in particular if this is higher than ten somatic mutations per megabase pair (corresponding to 150 nonsynonymous mutations within expressed genes). ${ }^{44}$ Among different tumor types, there is high variability in mutation frequency, but differences can also be seen within the same tumor type. ${ }^{60,61}$ For NSCLCs, substantial differences have been described between smokers and never smokers both in terms of mutational burden and affected genes. ${ }^{62}$ Smoking-induced lung cancers are characterized by a higher number of mutations per megabase pair compared to tumors of never smokers. ${ }^{61,63,64}$ In particular, Govindan et al described a median of 10.5 mutations per megabase pair (range: 4.9-17.6) in smokers and a median of 0.6 (range: 0.6-0.9) in never smokers. ${ }^{64}$ Recently, Rizvi et al have demonstrated a significantly improved efficacy of anti-PD-1 treatment for NSCLCs with a high nonsynonymous mutation burden, in terms of ORR, durable clinical benefit (ie, PR or SD lasting $\geq 6$ months), and PFS. ${ }^{61}$ Moreover, the benefit was greater for tumors harboring the "smoking signature" (ie, transversionhigh $[\mathrm{TH}])^{62}$ compared to those with transversion-low (TL) tumors (ORR: TH 56\% vs TL 17\%, $P=0.03$; durable clinical benefit: TH 77\% vs TL 22\%, $P=0.004$; PFS: TH not reached vs TL 3.5 months, $P=0.0001) .{ }^{61}$ Lastly, recent evidence that tumors with mismatch-repair deficiency achieve higher ORR and survival compared to mismatch-repair-proficient ones seems to support the hypothesis of a role for tumor mutation load and neo-antigens in predicting the response to anti-PD-1 treatments. ${ }^{65,66}$

\section{Safety and tolerability}

In general, nivolumab is well tolerated (Table 4), and patients' performance status has been reported not to affect treatment tolerability. ${ }^{45}$ In two Phase III trials, nivolumab was compared to docetaxel and was found to induce fewer grade 3-4 events

Table 4 Most common nivolumab-related immune-mediated adverse events and reported frequency in the main clinical trials

\begin{tabular}{|c|c|c|c|c|c|c|c|c|c|c|c|}
\hline \multirow[t]{2}{*}{ Study } & \multirow[t]{2}{*}{ Pts (n) } & \multicolumn{2}{|c|}{ Pneumonitis } & \multicolumn{2}{|l|}{ Diarrhea } & \multicolumn{2}{|c|}{ Hypothyroidism } & \multicolumn{2}{|c|}{ Skin toxicity } & \multicolumn{2}{|l|}{ Renal toxicity } \\
\hline & & $\begin{array}{l}\text { Any } \\
\text { grade }\end{array}$ & $\begin{array}{l}\text { Grade } \\
3-4\end{array}$ & $\begin{array}{l}\text { Any } \\
\text { grade }\end{array}$ & $\begin{array}{l}\text { Grade } \\
3-4\end{array}$ & $\begin{array}{l}\text { Any } \\
\text { grade }\end{array}$ & $\begin{array}{l}\text { Grade } \\
3-4\end{array}$ & $\begin{array}{l}\text { Any } \\
\text { grade }\end{array}$ & $\begin{array}{l}\text { Grade } \\
3-4\end{array}$ & Any grade & $\begin{array}{l}\text { Grade } \\
3-4\end{array}$ \\
\hline $\begin{array}{l}\text { Gettinger et al, }{ }^{40} \\
\text { Phase I (prolonged } \\
\text { FU NSCLC) } \\
\text { NCT00730639 }\end{array}$ & $\begin{array}{l}129 \\
\text { NSCLC }\end{array}$ & $8(6 \%)$ & $3(2 \%)$ & $13(10 \%)$ & I (I\%) & $N / R$ & $N / R$ & $\begin{array}{l}\text { Rash: } 9 \\
(7 \%)\end{array}$ & None & $N / R$ & $N / R$ \\
\hline $\begin{array}{l}\text { Rizvi et al, }{ }^{41} \text { Phase } \\
\text { Il (squamous } \\
\text { NSCLC), } \\
\text { CheckMate } 063 \\
\text { NCT0I72I759 }\end{array}$ & $\begin{array}{l}\text { II7 } \\
\text { NSCLC }\end{array}$ & $6(5 \%)$ & $4(3 \%)$ & $12(10 \%)$ & $3(3 \%)$ & $3(3 \%)$ & None & $\begin{array}{l}\text { Rash: I3 } \\
\text { (II\%) }\end{array}$ & I (I\%) & $4(3 \%)$ & None \\
\hline $\begin{array}{l}\text { Brahmer et al, }{ }^{8} \\
\text { Phase III (squamous } \\
\text { NSCLC), } \\
\text { CheckMate } 017 \\
\text { NCT0I642004 }\end{array}$ & $\begin{array}{l}|3| \\
\text { NSCLC } \\
\text { nivolumab }\end{array}$ & $6(5 \%)$ & I (I\%) & $10(8 \%)$ & None & $5(4 \%)$ & None & $\begin{array}{l}\text { Rash: } 5 \\
(4 \%)\end{array}$ & None & $\begin{array}{l}\text { Creatinine } \\
\text { increase } 4 \text { (3\%) } \\
\text { Nephritis I } \\
(1 \%)\end{array}$ & $\begin{array}{l}\text { None } \\
\text { I (1\%) }\end{array}$ \\
\hline $\begin{array}{l}\text { Borghaei et al," } \\
\text { Phase III (non- } \\
\text { squamous NSCLC), } \\
\text { CheckMate } 057 \\
\text { NCT0I673867 }\end{array}$ & $\begin{array}{l}287 \\
\text { NSCLC } \\
\text { nivolumab }\end{array}$ & $8(3 \%)$ & $3(1 \%)$ & $22(8 \%)$ & $2(1 \%)$ & $19(7 \%)$ & None & $\begin{array}{l}\text { Rash: } 27 \\
(9 \%)\end{array}$ & I (<I\%) & $\begin{array}{l}\text { Creatinine } \\
\text { increase } 5(2 \%) \\
\text { Renal failure I } \\
(1 \%)\end{array}$ & $\begin{array}{l}\text { None } \\
\text { None }\end{array}$ \\
\hline
\end{tabular}

Note: Data are presented as $n(\%)$.

Abbreviations: pts, patients; FU, follow-up; NSCLC, non-small-cell lung cancer; N/R, not reported. 
than chemotherapy ( $7 \%-10 \%$ vs $54 \%-55 \%$, respectively). ${ }^{8,9}$ Across different trials, ${ }^{8,9,40,41}$ treatment-related adverse events of any grade were reported in $58 \%-74 \%$ of the patients. The most frequent ones were fatigue, decreased appetite, and asthenia. Grade 3 or 4 adverse events were reported in $7 \%-17 \%$ of the patients, and the most common event was fatigue. No clear relationship between the occurrence of events and dose level or treatment duration was found. ${ }^{8,40}$

Given the mechanism of action of nivolumab, its most expected side effects are immune-related (irAEs). Their management is comparable to that of ipilimumab-related irAEs (Table 5). ${ }^{67}$

irAEs were reported in approximately half of NSCLC patients treated with nivolumab across different trials. The most common irAEs were skin toxicity $(5 \%-16 \%$, consisting mainly in rash and pruritus), gastrointestinal events $(8 \%-12 \%)$, and pneumonitis $(3 \%-6 \%)$, and in most cases, they were of low grade. ${ }^{8,40,41}$ Other less common irAEs included endocrinopathies $(4 \%-7 \%)$, elevation of blood liver function parameters ( $1 \%-3 \%)$, nephrotoxicity ( $2 \%-3 \%$, mainly consisting in blood creatinine elevation), and rare infusion reactions $(1 \%-3 \%)$.

Across different irAE categories, median time to onset (TTO) and time to resolution (TTR) ranged widely in the two Phase III trials by Brahmer et al (TTO: 0.3-17.6 weeks; TTR: 0.3-not reached $)^{8}$ and Borghaei et al (TTO: 0.1-31 weeks; TTR: $0.1-$ not reached). ${ }^{9}$ The longest median TTO was registered for endocrine, hepatic, and pulmonary toxicities. Most of nivolumab-related adverse events were manageable with supportive care and glucocorticoids treatment, as per protocol.

The most common irAE leading to nivolumab discontinuation was pneumonitis. ${ }^{8,40}$ Grade $3-4$ pneumonitis appeared in $1 \%-3 \%$ of the patients, and was generally manageable using corticosteroid treatment. In the trial of Borghaei et al, ${ }^{9}$ four patients $(1 \%)$ experienced a grade $3-4$ pulmonary adverse

Table 5 Management of the most common irAEs

\begin{tabular}{|c|c|c|c|}
\hline irAE & Grade I & Grade 2 & Grade 3-4 \\
\hline \multirow[t]{7}{*}{ Pneumonitis } & Consider discontinue treatment & Discontinue treatment & Discontinue treatment \\
\hline & X-ray every 3 days & $\begin{array}{l}\text { Start prednisone } 1 \mathrm{mg} / \mathrm{kg} / \mathrm{d} \text {, until } \\
\text { resolved to grade } 0-\mathrm{I}\end{array}$ & X-ray every 3 days \\
\hline & If no improvement: & X-ray every 3 days & Consider bronchoscopy/biopsy \\
\hline & Treat like grade 2 & If no improvement: & Start prednisone I mg/kg/d, until resolved to baseline \\
\hline & & Treat like grade $3-4$ & Taper prednisone in 6 weeks \\
\hline & & & If no improvement (in 48 hours): \\
\hline & & & Consider other immunosuppressive medication \\
\hline \multirow[t]{8}{*}{ Diarrhea } & Continue treatment & Discontinue treatment & Discontinue treatment \\
\hline & $\begin{array}{l}\text { Start symptomatic treatment (ie, } \\
\text { loperamide) }\end{array}$ & $\begin{array}{l}\text { Start symptomatic treatment } \\
\text { (ie, loperamide) }\end{array}$ & Start prednisolone I-2 mg/kg/d until grade 0-I \\
\hline & & Consider colonoscopy & Colonoscopy \\
\hline & & If no improvement: & IV hydration and other (symptomatic) treatment of \\
\hline & & Treat like grade $3-4$ & grade $3-4$ diarrhea \\
\hline & & & Taper prednisone in 5 weeks \\
\hline & & & If no improvement: \\
\hline & & & Consider infliximab \\
\hline \multirow[t]{6}{*}{ Hypothyroidism } & Continue treatment & Continue treatment & MRI hypophyses \\
\hline & Consider substitution therapy & Consider substitution therapy & Exclude other hormonal dysfunction \\
\hline & & & Consult endocrinologist \\
\hline & & & If abnormalities: \\
\hline & & & Discontinue treatment \\
\hline & & & Start prednisolone $\mathrm{I}-2 \mathrm{mg} / \mathrm{kg} / \mathrm{d}$ \\
\hline \multirow[t]{4}{*}{ Skin toxicity } & Continue treatment & Continue treatment & Discontinue treatment \\
\hline & $\begin{array}{l}\text { Consider local or oral treatment } \\
\text { (ie, topical steroids) }\end{array}$ & $\begin{array}{l}\text { Consider local or oral treatment } \\
\text { (ie, topical steroids) }\end{array}$ & Consult dermatologist \\
\hline & If no improvement (in 2 weeks): & If no improvement (in 2 weeks): & Start prednisone I-2 mg/kg/d, until resolved to grade I \\
\hline & $\begin{array}{l}\text { Consider a biopsy and oral } \\
\text { prednisone }\end{array}$ & $\begin{array}{l}\text { Consider a biopsy and oral } \\
\text { prednisone }\end{array}$ & Taper prednisone in 5 weeks \\
\hline \multirow[t]{4}{*}{ Renal toxicity } & Continue treatment & Discontinue treatment & Discontinue treatment \\
\hline & & Check creatinine every 3 days & Check creatinine every 3 days \\
\hline & & Start prednisone I mg/kg/d & Start prednisone I mg/kg/d, until resolved to grade I \\
\hline & & If no improvement (in 7 days): & Taper prednisone in 5 weeks \\
\hline
\end{tabular}

Note: Toxicity grading: as defined by CTCAE.

Abbreviations: irAEs, immune-related adverse events; IV, intravenous; MRI, magnetic resonance imaging; CTCAE, Common terminology criteria for adverse events. 
event (three pneumonitis; one interstitial lung disease). They were all treated with immune-modulating medication, and $75 \%$ of the events resolved completely. In the Phase II trial by Rizvi et al, all patients with pneumonitis were treated with steroids, and their median TTR was 3.4 weeks (1.6-13.4 weeks). ${ }^{41}$ Unresolved pneumonitis led to toxic death in three cases, all of them in the Phase I trial..$^{40}$

Diarrhea is another common irAE $(8 \%-10 \%)$, sometimes associated with colitis. ${ }^{8,9,40,41}$ Therefore, as in the management of ipilimumab-related irAEs, with a persistent grade 2 diarrhea, a sigmoidoscopy or colonoscopy could be considered to rule out colitis. ${ }^{67}$ Nevertheless, a grade 3-4 colitis was only reported in $<1 \%$ of the patients overall. These patients improved after treatment with either supportive care or immunosuppressive therapy. When there is no improvement in 48-72 hours, infliximab could be an alternative. ${ }^{67}$

Most commonly reported endocrine irAEs are thyroid impairments, such as hypothyroidism. ${ }^{8,941}$ Hypophysitis has not been reported. TTR was not reached for endocrinopathies in both Phase III trials, ${ }^{8,9}$ with a proportion of patients requiring prolonged substitution therapy with thyroid hormones. No grade 3 or 4 events were described in patients treated with nivolumab.

Treatment-related deaths were reported in two trials. In the Phase I trial by Gettinger et al, ${ }^{40}$ three cases of treatment-related deaths were described, associated with pneumonitis. Two of the patients had unresolved grade 4 pneumonitis, and the other one, grade 5 . Rizvi et $\mathrm{al}^{41}$ described two nivolumab-related deaths. One of the patients had rapid tumor progression and bronchial obstruction. An inflammatory component caused by nivolumab could not be ruled out because a bronchoscopy or autopsy was not performed. The second patient died of ischemic stroke 41 days after the only dose of nivolumab he got. Both these patients had multiple comorbidities.

In general, grade 1 or 2 irAEs are treated symptomatically (eg, loperamide for diarrhea), and discontinuation is not always necessary. For grade 3 and 4 irAEs, the treatment with nivolumab should be discontinued, and steroids (or other immunosuppressive therapy) should be started. For symptomatic endocrinopathy, substitution therapy might be required (Table 5). ${ }^{67}$

Other anti-PD1 and anti-PD-L1 compounds, such as pembrolizumab, showed a comparable safety pattern. No trials are currently available comparing the safety of these compounds. ${ }^{51}$

\section{Patient-focused perspectives: QoL and patient-reported outcomes}

Given the peculiar spectrum of immune-related side effects among nivolumab-treated patients, the evaluation of their
QoL is as relevant as the drug's clinical activity to make a comprehensive comparison with standard treatments. Few data are currently available, which suggest a good QoL for patients treated with nivolumab.

During the 2015 ASCO meeting, patient-reported outcomes from subjects with advanced melanoma, treated with either nivolumab or dacarbazine in CheckMate 066 trial, were reported. QoL questionnaire completion rates were $70 \%$ in the nivolumab arm and $64.9 \%$ in the dacarbazine arm. No improvement from basal QoL was described for dacarbazine-treated patients. On the contrary, nivolumab-induced QoL improvements from week 7 to week 61, registered with EuroQoL-Five Dimension questionnaire (EQ-5D), utilities and visual analog scale (VAS) scores. ${ }^{68}$ Similarly, in CheckMate 067 trial, nivolumab led to early QoL improvements compared to ipilimumab. ${ }^{69}$ Initial data are also available for nivolumab-ipilimumab combination regimens. These show that quality of life can be maintained at a similar level as with ipilimumab alone. ${ }^{69,70}$

For NSCLC, the only data available so far come from CheckMate 017 trial. In this study, the QoL questionnaire completion rates were $71.9 \%$ (97/135 patients) for the nivolumab arm and $64.2 \%$ (88/137 patients) for the docetaxel control group. A significant and progressive improvement in QoL (EQ-5D and EQ-VAS scores) was observed for subjects receiving nivolumab during the first year of treatment. EQ-VAS score was statistically higher than baseline at weeks $12,20,36$, and $48(P \leq 0.05)$, and similar results have been observed with EQ-5D index. Conversely, QoL for patients in the docetaxel arm showed no differences from baseline during their shorter treatment period. ${ }^{71}$ Results from CheckMate 057 trial are still awaited.

\section{Conclusion and future perspectives}

In the recent years, new immune-modulating agents have emerged as effective treatments for the management of different tumors. In particular, nivolumab has been demonstrated to achieve a survival improvement over chemotherapy in patients with advanced NSCLC, ${ }^{8,9}$ with a fraction of longterm survivors and a manageable toxicity profile. Given these striking results, nivolumab has recently been approved in the US and in Europe as second-line monotherapy for metastatic NSCLCs, of both squamous and non-squamous histologies. However, many questions are still open. Patients' selection is currently one of the biggest issues, both for treatment optimization and economic reasons. PD-L1 expression by tumor cells seems not to be sufficient to discriminate responders versus nonresponders, and new predictive factors are now under investigation. Tumor's mutational burden and neoantigens are emerging as promising predictive factors, ${ }^{44,61}$ and 
new diagnostic techniques are emerging to allow fast DNA sequencing, such as next-generation sequencing. ${ }^{72}$ However, their applicability in clinical practice still has to be defined together with conclusive data of ongoing trials. The role of nivolumab in the treatment of NSCLC in other clinical settings still has to be defined. A number of ongoing trials are currently investigating its efficacy as first-line and adjuvant therapy. The use of nivolumab in combination with other systemic agents is promising, in particular when combined with other immune checkpoint inhibitors. Finally, the duration of administration of the checkpoint inhibitors is not yet defined. Studies addressing this issue are ongoing. Immunotherapy is opening new perspectives for the treatment of lung cancer, giving new effective options for this highly fatal disease, and new results from the ongoing trials are awaited in the next years.

\section{Disclosure}

The authors report no conflicts of interest in this work.

\section{References}

1. Ferlay J, Soerjomataram I, Ervik M, et al. GLOBOCAN 2012 v1.2, cancer incidence and mortality worldwide: IARC cancerbase no. 11. Lyon: International Agency for Research on Cancer; 2015. Available from: http://globocan.iarc.fr/Pages/fact_sheets_cancer.aspx. Accessed January 7, 2016.

2. Jemal A, Bray F, Center MM, Ferlay J, Ward E, Forman D. Global cancer statistics. CA Cancer J Clin. 2011;61(2):69-90.

3. Reck M, Popat S, Reinmuth N, DeRuysscher D, Kerr KM, Peters S. Metastatic non-small-cell lung cancer (NSCLC): ESMO Clinical Practice Guidelines for diagnosis, treatment and follow-up. Ann Oncol. 2014;25(Suppl 3):iii27-iii39.

4. Ettinger DS, Wood DE, Akerley W, et al. NCCN Clinical Practice guidelines in oncology. Non-small cell lung cancer. Version 7. 2015. Available from: http://www.cjcpt.org/files/2015/03-06/2015-NCCN/2015\%20 NCCN-\%E9\%9D\%9E\%E5\%B0\%8F\%E7\%BB\%86\%E8\%83\%9E\% E8\%82\%BA\%E7\%99\%8C-V3.pdf.

5. Naidoo J, Drilon A. Molecular diagnostic testing in non-small cell lung cancer. Am J Hematol Oncol. 2014;10(4):4-11.

6. Kerr KM, Bubendorf L, Edelman MJ, et al. Second ESMO consensus conference on lung cancer: pathology and molecular biomarkers for non-small-cell lung cancer. Ann Oncol. 2014;25:1681-1690.

7. Pardoll DM. Immunology beats cancer: a blueprint for successful translation. Nat Immunol. 2012;13(12):1129-1132.

8. Brahmer J, Reckamp KL, Baas P, et al. Nivolumab versus docetaxel in advanced squamous-cell non-small-cell lung cancer. $N$ Engl J Med. 2015;373:123-135.

9. Borghaei H, Paz-Ares L, Horn L, et al. Nivolumab versus docetaxel in advanced nonsquamous non-small-cell lung cancer. $N$ Engl J Med. 2015;373:1627-1639.

10. Schiller JH, Harrington D, Belani CP, et al. Comparison of four chemotherapy regimens for advanced non-small cell lung cancer. $N$ Engl J Med. 2002;346(2):92-98.

11. Ardizzoni A, Boni L, Tiseo M, et al. Cisplatin- versus carboplatin-based chemotherapy in first-line treatment of advanced non-small-cell lung cancer: an individual patient data meta-analysis. J Natl Cancer Inst. 2007;99:847-857.

12. Scagliotti GV, Parikh P, von Pawel J, et al. Phase III study comparing cisplatin plus gemcitabine with cisplatin plus pemetrexed in chemotherapy-naive patients with advanced-stage non-small-cell lung cancer. J Clin Oncol. 2008;26(21):3543-3551.
13. Mok TS, Wu Y, Thongprasert S, et al. Gefitinib or carboplatin-paclitaxel in pulmonary adenocarcinoma. $N$ Engl J Med. 2009;361(10): 947-957.

14. Rosell R, Carcereny E, Gervais R, et al. Erlotinib versus standard chemotherapy as first-line treatment for European patients with advanced EGFR mutation-positive non-small-cell lung cancer (EURTAC): a multicentre, open-label, randomised phase 3 trial. Lancet Oncol. 2012;13:239-246.

15. Sequist LV, Yang C, Yamamoto N, et al. Phase III study of afatinib or cisplatin plus pemetrexed in patients with metastatic lung adenocarcinoma with EGFR mutations. J Clin Oncol. 2013;31(27): 3327-3334.

16. Wu YL, Zhou C, Hu CP, et al. Afatinib versus cisplatin plus gemcitabine for first-line treatment of Asian patients with advanced non-small-cell lung cancer harbouring EGFR mutations (LUX-Lung 6): an open-label, randomised phase 3 trial. Lancet Oncol. 2014;15:213-222.

17. Shaw AT, Kim D, Nakagawa K, et al. Crizotinib versus chemotherapy in advanced ALK-positive lung cancer. $N$ Engl J Med. 2013;368:2385-2394.

18. Solomon BJ, Mok T, Kim D, et al. First-line crizotinib versus chemotherapy in ALK-positive lung cancer. N Engl J Med. 2014;371:2167-2177.

19. Jänne PA, Yang JC, Kim D, et al. AZD9291 in EGFR inhibitor-resistant non-small-cell lung cancer. N Engl J Med. 2015;372(18):1689-1699.

20. Sequist LV, Soria JC, Goldman JW, et al. Rociletinib in EGFR-mutated non-small-cell lung cancer. $N$ Engl J Med. 2015;372(18):1700-1709.

21. Shaw AT, Kim D, Mehra R, et al. Ceritinib in ALK-rearranged nonsmall-cell lung cancer. N Engl J Med. 2014;370(13):1189-1197.

22. Seto T, Kiura K, Nishio M, et al. CH5424802 (RO5424802) for patients with ALK-rearranged advanced non-small-cell lung cancer (AF-001JP study): a single-arm, open-label, phase 1-2 study. Lancet Oncol. 2013;14: 590-598.

23. Gadgeel SM, Gandhi L, Riely G, et al. Safety and activity of alectinib against systemic disease and brain metastases in patients with crizotinibresistant ALK-rearranged non-small-cell lung cancer(AF-002JG): results from the dose-finding portion of a phase 1/2 study. Lancet Oncol. 2014;15: 1119-1128.

24. Shaw AT, Ou S, Bang Y, et al. Crizotinib in ROS1-rearranged non-smallcell lung cancer. $N$ Engl J Med. 2014;371(21):1963-1971.

25. Camidge DR, Ou SI, Shapiro G, et al. Efficacy and safety of crizotinib in patients with advanced c-MET-amplified non-small cell lung cancer (NSCLC). J Clin Oncol. 2014;32(Suppl 5):abstr 8001.

26. Planchard D, Kim TM, Mazierez J, et al. LBA38_PR - dabrafenib in patients with BRAF V600E-mutant advanced non-small cell lung cancer (NSCLC): a multicenter, open-label, phase II trial (BRF113928). Ann Oncol. 2014;25(suppl 4).

27. Planchard D, Groen HJ, Kim TM, et al. Interim results of a phase II study of the BRAF inhibitor (BRAFi) dabrafenib (D) in combination with the MEK inhibitor trametinib (T) in patients (pts) with BRAF V600E mutated (mut) metastatic non-small cell lung cancer (NSCLC). J Clin Oncol. 2015;33(Suppl):abstr 8006.

28. Manzières J, Peters S, Lepage B, et al. Lung cancer that harbors an HER2 mutation: epidemiologic characteristics and therapeutic perspectives. $J$ Clin Oncol. 2013;31(16):1997-2003.

29. Champiat S, Ferté C, Lebel-Binay S, Eggermont A, Soria JC. Exomics and immunogenics. Oncoimmunology. 2014;3:e27817.

30. Pardoll DM. The blockade of immune checkpoints in cancer immunotherapy. Nat Rev Cancer. 2012;12:252-264.

31. Ribas A. Tumor immunotherapy directed at PD-1. N Engl J Med. 2012; 366(26):2517-2519.

32. Nishimura H, Nose M, Hiai H, Minato N, Honjo T. Development of lupus-like autoimmune diseases by disruption of the PD-1 gene encoding an ITIM motif-carrying immunoreceptor. Immunity. 1999;11: 141-151.

33. Nishimura H, Okazaki T, Tanaka Y, et al. Autoimmune dilated cardiomyopathy in PD-1 receptor-deficient mice. Science. 2001;291:319-322.

34. Hirano F, Kaneko K, Tamura H, et al. Blockade of B7-H1 and PD-1 by monoclonal antibodies potentiates cancer therapeutic immunity. Cancer Res. 2005;65(3):1089-1096. 
35. Wong RM, Scotland RR, Lau RL, et al. Programmed death-1 blockade enhances expansion and functional capacity of human melanoma antigen-specific CTLs. Int Immunol. 2007;19(10):1223-1234.

36. Curiel TJ, Wei S, Dong H, et al. Blockade of B7-H1 improves myeloid dendritic cell-mediated antitumor immunity. Nat Med. 2003;9(5):562-567.

37. Wang C, Thudium KB, Han M, et al. In vitro characterization of the anti-PD-1 antibody nivolumab, BMS-936558, and in vivo toxicology in non-human primates. Cancer Immunol Res. 2014;2(9):846-856.

38. Brahmer JR, Drake CG, Wollner I, et al. Phase I study of single-agent anti-programmed death-1 (MDX-1106) in refractory solid tumors: safety, clinical activity, pharmacodynamics, and immunologic correlates. J Clin Oncol. 2010;28(19):3167-3175.

39. Topalian SL, Hodi FS, Brahmer JR, et al. Safety, activity, and immune correlates of anti-PD-1 antibody in cancer. $N$ Engl $J$ Med. 2012;366(26):2443-2454.

40. Gettinger SN, Horn L, Gandhi L, et al. Overall survival and long-term safety of nivolumab (anti-programmed death 1 antibody, BMS-936558, ONO-4538) in patients with previously treated advanced non-small-cell lung cancer. J Clin Oncol. 2015;33(18):2004-2012.

41. Rizvi NA, Mazières J, Planchard D, et al. Activity and safety of nivolumab, an anti-PD-1 immune checkpoint inhibitor, for patients with advanced, refractory squamous non-small-cell lung cancer (CheckMate 063): a phase 2, single-arm trial. Lancet Oncol. 2015;16:257-265.

42. Horn L, Rizvi NA, Mazieres J, et al. Longer-term follow-up of a phase 2 study (CheckMate 063) of nivolumab in patients with advanced, refractory squamous non-small cell lung cancer. Paper presented at: 16th World Conference on Lung Cancer (WCLC); September 6-9, 2015; Denver, CO.

43. Nishio M, Hida T, Nakagawa $\mathrm{K}$, et al. Phase II studies of nivolumab (anti-PD-1, BMS-936558, ONO-4538) in patients with advanced squamous (sq) or nonsquamous (non-sq) non-small cell lung cancer (NSCLC). J Clin Oncol. 2015;33(Suppl):abstr 8027.

44. Schumacher TN, Schreiber RD. Neoantigens in cancer immunotherapy. Science. 2015;348(6230):69-74.

45. Hussein M, McCleaod M, Chandler J, et al. Safety and efficacy of nivolumab in an ongoing trial of a PD-L1+/- patient population with metastatic non-small cell lung cancer. Paper presented at: 16th World Conference on Lung Cancer; September 6-9, 2015; Denver, CO.

46. Gettinger SN, Hellmann MD, Shepherd FA, et al. First-line monotherapy with nivolumab (NIVO; anti-programmed death-1 [PD-1]) in advanced non-small cell lung cancer (NSCLC): safety, efficacy and correlation of outcomes with PD-1 ligand (PD-L1) expression. J Clin Oncol. 2015;33(Suppl):abstr 8025.

47. Carbone DP, Socinski MA, Chen AC, Bhagavatheeswaran P, Reck M, Paz-Ares L. A phase III, randomized, open-label trial of nivolumab (anti-PD-1; BMS-936558, ONO-4538) versus investigator's choice chemotherapy (ICC) as first-line therapy for stage IV or recurrent PD-L1+ non-small cell lung cancer (NSCLC). J Clin Oncol. 2014;32(Suppl 5): abstr TPS 8281.

48. Rizvi N, Gettinger SN, Goldman J, et al. Safety and efficacy of firstline nivolumab (anti-programmed death-1 [PD-1]) and ipilimumab in non-small cell lung cancer (NSCLC). Paper presented at: 16th World Conference on Lung Cancer; September 6-9, 2015; Denver, CO.

49. Postow MA, Chesney J, Pavlick AC, et al. Nivolumab and ipilimumab versus ipilimumab in untreated melanoma. $N$ Engl J Med. 2015; 372:2006-2017.

50. Larkin J, Chiarion-Sileni V, Gonzalez R, et al. Combined nivolumab and ipilimumab or monotherapy in untreated melanoma. $N$ Engl J Med. 2015;373:23-34.

51. Herbst RS, Baas P, Kim DW, et al. Pembrolizumab versus docetaxel for previously treated, PD-L1-positive, advanced non-small-cell lung cancer (KEYNOTE-010): a randomised controlled trial. Lancet Oncol. 2016;387:1540-1550.

52. Fehrenbacher L, Spira A, Ballinger M, et al. Atezolizumab versus docetaxel for patients with previously treated non-small-cell lung cancer (POPLAR): a multicentre, open-label, phase 2 randomised controlled trial. Lancet. 2016;387:1837-1846.
53. Eisenhauer EA, Therasse P, Bogaerts J, et al. New response evaluation criteria in solid tumours: revised RECIST guidelines (version 1.1). Eur J Cancer. 2009;45:228-247.

54. Wolchok JD, Hoos A, O'Day S, et al. Guidelines for the evaluation of immune therapy activity in solid tumors: immune-related response criteria. Clin Cancer Res. 2009;15(23):7412-7420.

55. Carbognin L, Pilotto S, Milella M, et al. Differential activity of nivolumab, pembrolizumab and MPDL3280A according to the tumor expression of programmed death-ligand-1 (PD-L1): sensitivity analysis of trials in melanoma, lung and genitourinary cancers. PLoS One. 2015;10(6): $\mathrm{e} 0130142$

56. Garon EB, Rizvi NA, Rina H, et al. Pembrolizumab for the treatment of non-small-cell lung cancer. N Engl J Med. 2015;372:2018-2028.

57. McLaughlin J, Han G, Schalper KA, et al. Quantitative assessment of the heterogeneity of PD-L1 expression in non-small cell lung cancer. JAMA Oncol. 2016;2(1):46-54.

58. Meng X, Huang Z, Teng F, Xing L, Yu J. Predictive biomarkers in PD-1/PD-L1 checkpoint blockade immunotherapy. Cancer Treat Rev. 2015;41(10):868-876.

59. Reynders K, Illidge T, Siva S, Chang JY, De Ruysscher D. The abscopal effect of local radiotherapy: using immunotherapy to make a rare event clinically relevant. Cancer Treat Rev. 2015;41:503-510.

60. Lawrence MS, Stojanov P, Polak P, et al. Mutational heterogeneity in cancer and the search for new cancer-associated genes. Nature. 2013; 499:214-218.

61. Rizvi NA, Hellmann MD, Snyder A, et al. Mutational landscape determines sensitivity to PD-1 blockade in non-small cell lung cancer. Science. 2015;348:124-128.

62. Alexandrov LB, Nik-Zainal S, Wedge DC, et al. Signatures of mutational processes in human cancer. Nature. 2013;500:415-421.

63. Lee W, Jiang Z, Liu J, et al. The mutation spectrum revealed by paired genome sequences from a lung cancer patient. Nature. 2010;465: 473-477.

64. Govindan R, Ding L, Griffith M, et al. Genomic landscape of nonsmall cell lung cancer in smokers and never-smokers. Cell. 2012;150: 1121-1134.

65. Le DT, Uram JN, Wang H, et al. PD-1 blockade in tumors with mismatch-repair deficiency. N Engl J Med. 2015;372:2509-2520.

66. Keldeman S, Schumacher TN, Kvistborg P. Mismatch repair-deficient cancers are targets for anti-PD-1 therapy. Cancer Cell. 2015;28(1): $11-13$.

67. Weber JS, Kähler KC, Hauschild A. Management of immune-related adverse events and kinetics of response with ipilimumab. J Clin Oncol. 2012;30(21):2691-2697.

68. Long GV, Atkinson V, Ascierto PA, et al. Effect of nivolumab (NIVO) on quality of life $(\mathrm{QoL})$ in patients (pts) with treatment-naïve advanced melanoma (MEL): results of a phase III study (CheckMate 066). J Clin Oncol. 2015;33(Suppl):abstr 9027.

69. Schadendorf D, Long G, Larkin J, et al. Patient reported outcomes (PROs) from a phase 3 study of nivolumab (NIVO) alone or combined with ipilimumab (IPI) versus IPI in patients with advanced melanoma (MEL): CheckMate 067. Paper presented at: Society for Melanoma Research Congress; November 18-21, 2015; San Francisco, CA.

70. Abernethy AP, Postow MA, Chesney JA, et al. Effect of nivolumab (NIVO) in combination with ipilimumab (IPI) versus IPI alone on quality of life $(\mathrm{QoL})$ in patients (pts) with treatment-naïve advanced melanoma (MEL): results of a phase II study (CheckMate 069). J Clin Oncol. 2015;33(Suppl):abstr 9029.

71. Reck M, Coon C, Taylor F, et al. Evaluation of overall health status in patients with advanced squamous non-small cell lung cancer treated with nivolumab or docetaxel in CheckMate 017. Paper presented at: European Cancer Congress; September 25-29, 2015; Vienna.

72. Grada A, Weinbrecht $\mathrm{K}$. Next-generation sequencing: methodology and application. J Invest Dermatol. 2013;133(8):e11.

73. National Cancer Institute. SEER Cancer Statistics Review 1975-2012. Available from: http://seer.cancer.gov/csr/1975_2012/. Accessed January 7, 2016. 
74. Maemondo M, Inoue A, Kobayashi K, et al. Gefitinib or chemotherapy for non-small-cell lung cancer with mutated EGFR. NEJM. 2010 362:2380-2388.

75. Yang JC, Sequist LV, Geater SL, et al. Clinical activity of afatinib in patients with advanced non-small-cell lung cancer harbouring uncommon EGFR mutations: a combined post-hoc analysis of LUX-Lung 2, LUX-Lung 3, and LUX-Lung 6. Lancet Oncol. 2015;16(7):830-838.

76. Solomon BJ, Mok T, Kim DW, et al. First-line crizotinib versus chemotherapy in ALK-positive lung cancer. NEngl JMed. 2015;16(2):141-145.
77. Mazières J, Peters S, Lepage B, et al. Lung cancer that harbors an HER2 mutation: epidemiologic characteristics and therapeutic perspectives. J Clin Oncol. 2013;31(16):1997-2003.

78. Drilon A, Wang L, Hasanovic A, et al. Response to Cabozantinib in patients with RET fusion-positive lung adenocarcinomas. Cancer Discov. 2013;3(6):630-635.

79. Robert C, Long GV, Brady B, et al. Nivolumab in previously untreated melanoma without BRAF mutation. $N$ Engl J Med. 2015;372(4): $320-330$.

\section{Publish your work in this journal}

Biologics: Targets and Therapy is an international, peer-reviewed journal focusing on the patho-physiological rationale for and clinical application of Biologic agents in the management of autoimmune diseases, cancers or other pathologies where a molecular target can be identified. This journal is indexed on PubMed Central, EMBase, and Scopus.

\section{Dovepress}

The manuscript management system is completely online and includes a very quick and fair peer-review system, which is all easy to use. Visit http://www.dovepress.com/testimonials.php to read real quotes from published authors. 